\title{
Geohydrology of
}

Project Gnome Site,

\section{Eddy County, New Mexico}

GEOLOGICAL SURVEY PROFESSIONAL PAPER 712-A

Prepared in cooperation with the U.S. Atomic Energy Commission

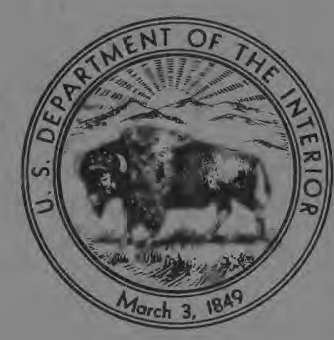



Geohydrology of

Project Gnome Site,

Eddy County, New Mexico

By JAMES B. COOPER and V. M. GLANZMAN

HYDROLOGY OF NUCLEAR TEST SITES

GEOLOGICAL SURVEY PROFESSIONAL PAPER 712-A

Prepared in cooperation with the

U.S. Atomic Energy Commission

UNITED STATES GOVERNMENT PRINTING OFFICE, WASHINGTON : 1971 
UNITED STATES DEPARTMENT OF THE INTERIOR

ROGERS G. B. MORTON, Secretary

\section{GEOLOGICAL SURVEY}

W. A. Radlinski, Acting Director

Library of Congress catalog-card No. 70-179645

For sale by the Superintendent of Documents, U.S. Government Printing Office

Washington, D.C. 20402 - Price $\$ 1$ (paper cover)

Stock Number 2401-1165 


\section{CONTENTS}

Abstract

Introduction

Location and physiographic setting . .

Methods of investigation . . . . . .

Well-numbering system

Geology

Regional setting

Strati graphy

Castile Formation

Salado Formation

Rustler Formation.

Dewey Lake Redbeds

Triassic formations.

Tertiary formations

Quaternary formations

\begin{tabular}{r|r} 
Page & Ground water. \\
1 & Availability and utilization \\
1 & Aquifer characteristics at and near project site \\
2 & Transmissivity and storage coefficient \\
2 & Aquifer yield \\
2 & Test holes at and near project site \\
2 & Construction \\
4 & Testing \\
6 & Initial investigation of water wells within 15 miles of \\
6 & project site \\
6 & Observations at time of nuclear explosion \\
8 & Investigations after the nuclear explosion \\
8 & Water-level fluctuations \\
8 & Effects of atmospheric pressure and earth tides. \\
8 & Senclusions.
\end{tabular}

Page

A8

10

10

11

11

12

13

14

14

17

20

20

20

21

22

\section{L L U S T R A T I O N S}

Plate 1. Map showing location of wells and water-level contours for geologic formations in the Project Gnome area, Eddy and Lea Counties, New Mexico.

Figure 1. Map showing location of the Project Gnome site and the area of investigation

2. Well-numbering system

4. Geologic section between Carlsbad Caverns National Park and the Project Gnome site geographic features

5. Generalized stratigraphic section at Project Gnome site

6. Map showing general distribution of water-bearing formations in the Project Gnome area.....

7. Map showing location of U.S. Geological Survey test holes near the Project Gnome site

8. Calculated time-drawdown plot of water level in U.S. Geological Survey test hole 1, when pumped continuously, at selected rates, Project Gnome site...

9. Hydrographs showing fluctuation of water level in U.S. Geological Survey test hole 1 prior to the nuclear explosion, Project Gnome site

10. Hydrograph showing fluctuation of water level in U.S. Geological Survey test hole 4 at time of Project Gnome explosion, Project Gnome site.

11. Hydrograph of water level in U.S. Geological Survey test hole 1, 1960-63, Project Gnome site $\ldots$

12. Graphs showing fluctuations of water level in U.S. Geological Survey test hole 1 and inverted fluctuations of atmospheric pressure, January 9-14, 1963, Project Gnome site

\section{T A B L E S}

TABLE 1. Generalized section of the rocks exposed in the Project Gnome area

2. Records of wells in the Project Gnome area

3. Chemical analyses of water samples from wells in the Project Gnome area

4. Radiochemical analyses of well water in the Project Gnome area

5. Water wells within a 5-mile radius of Project Gnome site, Eddy County 



\title{
GEOHYDROLOGY OF PROJEGT GNOME SITE, EDDY COUNTY NEW MEXICO
}

\author{
By James B. Cooper and V. M. Glanzman
}

\begin{abstract}
On December 10, 1961, a nuclear device was detonated 1,200 feet underground in the massive salt of the Salado Formation in southeastern Eddy County, N. Mex. In support of the public safety program of the U.S. Atomic Energy Commission, the water regimen of about 1,200 square miles, mostly east of the Pecos River and within 15 miles of the project site, was investigated before, at the time of, and after the explosion. Preliminary investigations determined that about 70 wells were in use in the area around the Project Gnome site. The wells range in depth from a few tens of feet to nearly 800 feet and tap water in rocks of Permian, Triassic, Tertiary, and Quaternary ages. Most ground water in the area is saline; however, it is a valuable resource utilized for stock water. Seven test holes drilled at the project site penetrated similar sequences of rocks overlying the massive salt.

All aquifers in the Project Gnome area lie above the massive salt of the Salado Formation. The only water at the project site is contained in the Culebra Dolomite Member of the Rustler Formation, a confined aquifer about 30 feet thick. The aquifer is about 500 feet beneath the surface and about 200 feet above the top of the salt. The potentiometric surface for the confined water is 75 feet above the top of the aquifer and slopes 0.2 to 1.0 foot per mile westward. Fluctuations of water levels observed in wells are small. Data from a pumping test on the aquifer at the Project Gnome site indicate that 100 gallons per minute could be pumped continuously from a well for as long as 1 year without lowering pumping levels below the top of the aquifer. Pressure changes in the aquifer due to the release of water through drill holes and removal by bailing were easily detected by a recording gage.

Water levels in four observation wells at the site were being recorded at the time of the nuclear explosion. The estimated maximum rise of water level immediately following the explosion was about 4 feet at a distance of 2,000 feet from ground zero. About 3,200 feet from ground zero, the water level rose about 2.2 feet, then gradually returned to normal level within a period of about 11 hours. Water in the four test holes returned to preexplosion levels 2 days after the explosion.

Continued observations of water level in those holes and three additional observation wells indicated no anomalous water-level fiuctuations after the nuclear explosion, suggesting that the aquifer probably was not significantly ruptured by the explosion.
\end{abstract}

\section{INTRODUCTION}

Project Gnome, an underground nuclear experiment, is a part of the U.S. Atomic Energy Commission Plowshare Program which is directed toward the development of peaceful industrial, scientific, and civilian uses of nuclear explosions. The Project Gnome nuclear device was detonated December 10, 1961, at 1200 m.s.t., about 25 miles southeast of Carlsbad, N. Mex., in an underground chamber approximately 1,200 feet below the earth's surface in a thick, massive salt formation.

The U.S. Geological Survey, in support of the public safety program of the U.S. Atomic Energy Commission, made studies and investigations relative to Project Gnome to provide information on the water regimen of the project site and surrounding area before and after the explosion. Primary objectives of the studies were (1) determination of the hazard, if any, of the underground nuclear explosion contaminating surface or ground waters, and (2) if such waters were contaminated, determination of their rate of movement and of the possible maximum concentration levels of contaminants in them. Preliminary studies of the physical properties of the rocks by other investigators indicated that the explosion would not rupture the beds above those containing the explosion chamber.

This report described the hydrology and the general geology of the Project Gnome area and project site and discusses studies of ground-water hydraulics made by the Geological Survey after the nuclear explosion.

\section{LOCATION AND PHYSIOGRAPHIC SETTING}

Ground-water and geologic investigations were made in an area of more than 1,200 square miles in southeastern Eddy County and southwestern Lea County, N. Mex. The site of Project Gnome is in the approximate center of this area, in sec. 34, T. 23 S., R. 30 E., Eddy 
County, east of the Pecos River about 25 miles southeast of Carlsbad (fig. 1). Detailed investigations of water wells were made within a 5-mile radius of the Project Gnome site.

The Project Gnome area is sparsely populated and is utilized for cattle ranching, farming, potash mining, and petroleum production. The climate is semiarid; the average annual precipitation is about 12 inches. Drilled wells are the principal source of water for livestock and domestic uses.

The site is in the Pecos Valley section of the Great Plains physiographic province. The Pecos River flows through the southwestern part of the area and divides the area physiographically into two sections; east of the river, the Mescalero pediment, and west of the river, the alluvial plain north of Malaga and the Gypsum Hills south of Malaga. The land surface east of the river slopes about 30 feet per mile westward and is chiefly a karst surface with numerous depressions ranging in width from a few tens of feet to about 5 miles. Nash Draw, the largest depression, extends southward through the west-central part of the area. Within it are several smaller depressions, the largest of which is Laguna Grande de la Sal (Salt Lake). Much of the land surface west of the river is mantled by dune sands, although in places on the uplands, caliche is exposed, and older formations crop out elsewhere.

\section{METHODS OF INVESTIGATION}

Reconnaissance fieldwork for this investigation was done in October 1958. Wells were located, water levels measured, and water samples, well logs, and other subsurface data collected from February through May 1959. Fifteen wells, nine of which were located within a 5 -mile radius of the Project Gnome site, were investigated during March and April 1959. The wells within the 5-mile radius were reinvestigated in December 1961. From July 1960 to June 1961, observations were made in the shaft and tunnel that were being constructed for access to the detonation point.

Geological Survey test holes 1, 2, 4, and 5 were drilled near the site to expand knowledge of the water-bearing formations in the immediate vicinity of the site and to provide water-level observation wells during the nuclear experiment. Geological Survey test holes 4 and 5 were completed in December 1961 just before the detonation.

Several reports on specific aspects of the ground water of the Project Gnome area and site have been issued as preliminary or progress reports. These reports, as well as other reports used for background infomation, are listed under "Selected References."

\section{WELL-NUMBERING SYSTEM}

All wells referred to in this report are identified by a location number used by the Geological Survey and the State Engineer for numbering water wells in New Mexico. The location number is a description of the geographic location of the well, based on the system of public land surveys. It indicates the location of the well to the nearest 10-acre tract, if the well can be located that accurately. The location number consists of a series of numbers corresponding to the township, range, section, and tract within a section, in that order, as illustrated in figure 2 . If a well has not been located closely enough to be placed within a particular section or tract, a zero is used for that part of the number. Letters $a, b$, and $c$ are added to the number to designate the second, third, and fourth wells in the same 10-acre tract. .

\section{GEOLOGY}

\section{REGIONAL SETTING}

The Project Gnome site is in the northern part of the Delaware basin (Adams, 1944; King, 1948; and Newell and others, 1953), a deep oval sedimentary basin about 135 miles long and 75 miles wide in southeastern New Mexico and western Texas. This structural basin is generally considered to be the area surrounded by the Capitan Limestone (a reef limestone of Late Permian age) (fig. 3). With notable exceptions, the Capitan Limestone is buried beneath the present land surface. West and southwest of Carlsbad, it is at the surface and forms La Barrera del Guadalupe and El Capitan Peak. Large caverns-primarily Carlsbad Caverns-were formed in the reef limestone through the solvent action of circulating ground water.

Southeastern New Mexico and adjacent parts of Texas were submerged beneath the sea in Permian time, and the pre-Permian rocks were buried beneath an accumulation of sediments. The irregular floor of the sea was characterized by structural basins, platforms, and broad shelves. Fine sand and limestone accumulated in the basins; reefs formed on the margins of the shelves and platforms; limestone and sand accumulated immediately behind the landward side of the reefs; and gypsum, anhydrite, other evaporite rocks, and silt and clay accumulated in the shallow waters of the shelves. Eventually, the reef growth was halted by increasing salinity of the sea water, and evaporite sediments (Castile, Salado, and Rustler Formations) were deposited in the Delaware basin. Evaporite deposition was interrupted during two intervals of time, during which the water was less saline and limestone was deposited. Toward the end of Permian time, deposition of the evapo- 
GEOHYDROLOGY OF PROJECT GNOME SITE, NEW MEXICO

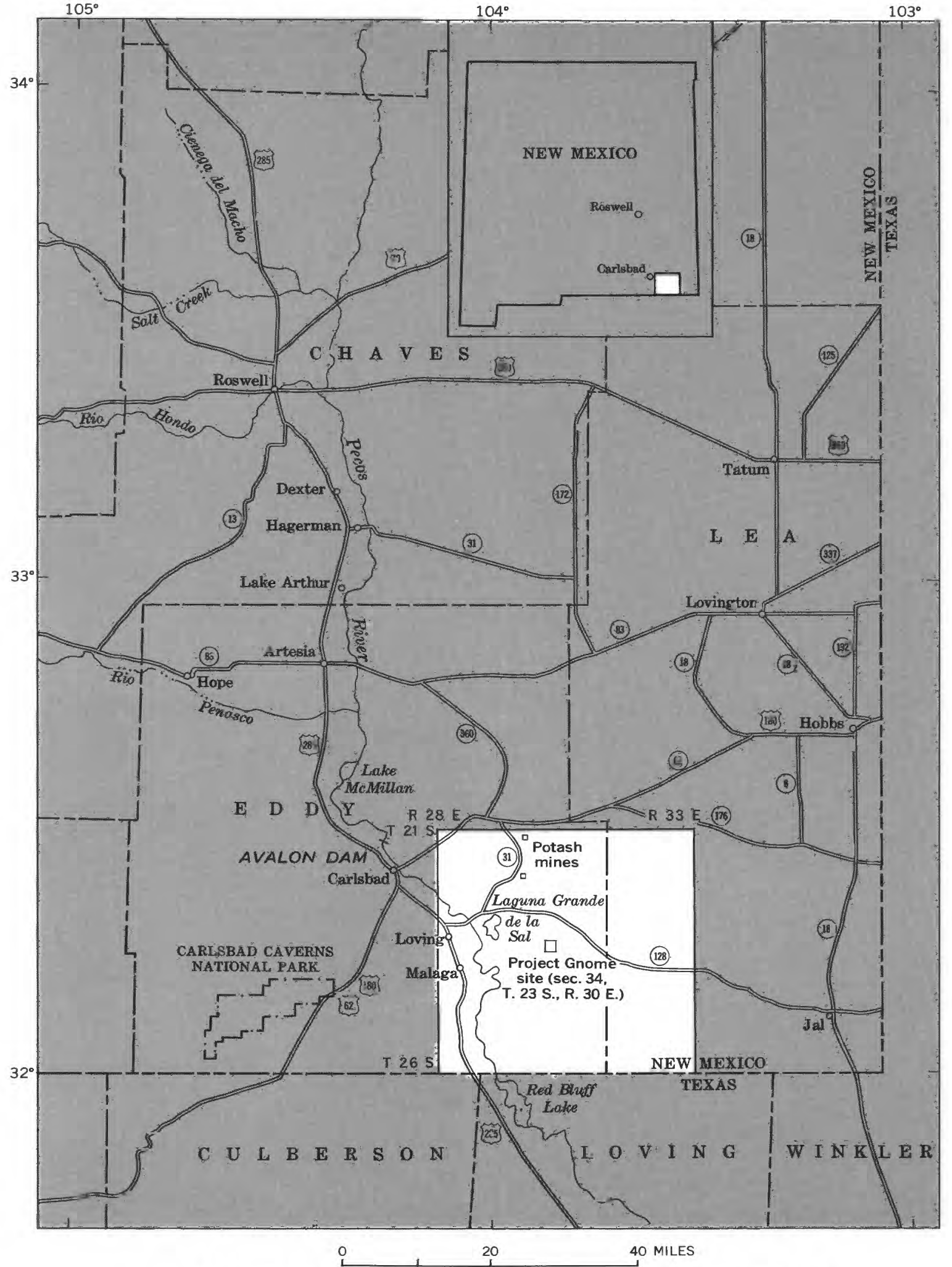

Figure 1.-Lacation of the Project Gnome site and the area of investigation (unshaded). 


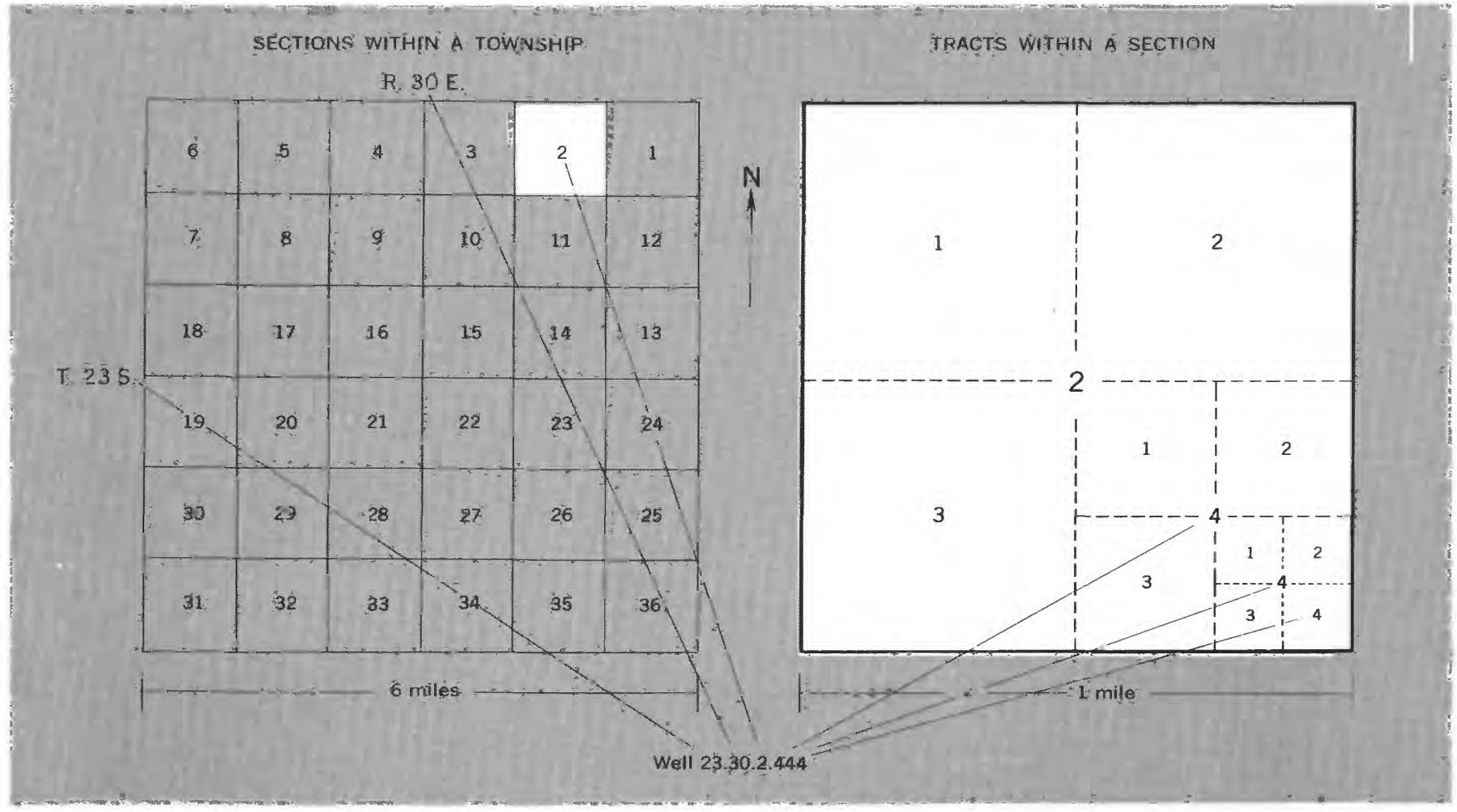

Ftgure 2.-Well-numbering system.

rite rocks ceased and deposition of terrestrial red beds (Dewey Lake Redbeds) began. Terrestrial deposition continued during parts of Triassic time. Additional thin deposits of sediments accumulated in Quaternary time. A total of 18,500 feet of sedimentary material, including pre-Permian sedimentary rocks, was deposited in places in the Delaware basin. A geologic section between Carlsbad Caverns National Park and the Project Gnome site is shown in figure 4.

\section{STRATIGRAPHY}

Sedimentary rocks of Permian to Quaternary age crop out in the Project Gnome area. The strata dip gently east and southeast, and older rocks are mantled progressively to the east by younger formations. The oldest exposed rocks crop out at the western margin of the area and belong to the Castile Formation of Permian age. Rocks of the Rustler Formation of Permian age crop out in numerous exposures in the west-central part of the area and in the Gypsum Hills south of Malaga. The Dewey Lake Redbeds of Permian age are exposed at several localities and crop out in a narrow and discontinuous north-south belt a few miles east of the Pecos River in the north-central part of the area. Rocks of Triassic age are represented by the Santa Rosa Sandstone in the north-central and southeastern parts of the area. Unconsolidated rocks of Tertiary age crop

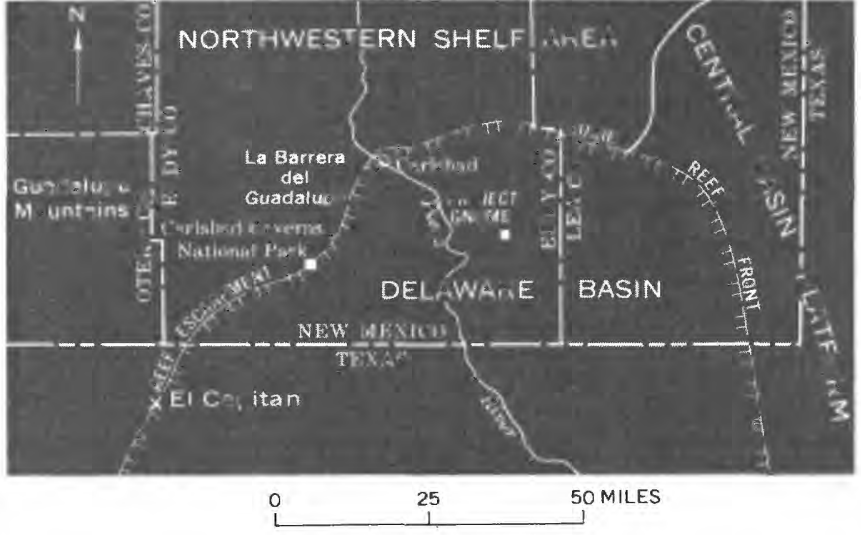

Figure 3.-Extent of the Delaware basin in New Mexico, and adjacent structural and geographic features. After King (1948) and Stipp and Hagler (1956).

out near the eastern margin of the area. Rocks of Quaternary age are the Gatuna Formation of Pleistocene (?) age and alluvium, windblown sand, caliche, and playa lake deposits of Holocene age. A generalized section of the rocks exposed in the Project Gnome area is given in table 1.

Regional structural features of the rocks are due to the regional dip of the beds in the subsurface and to 


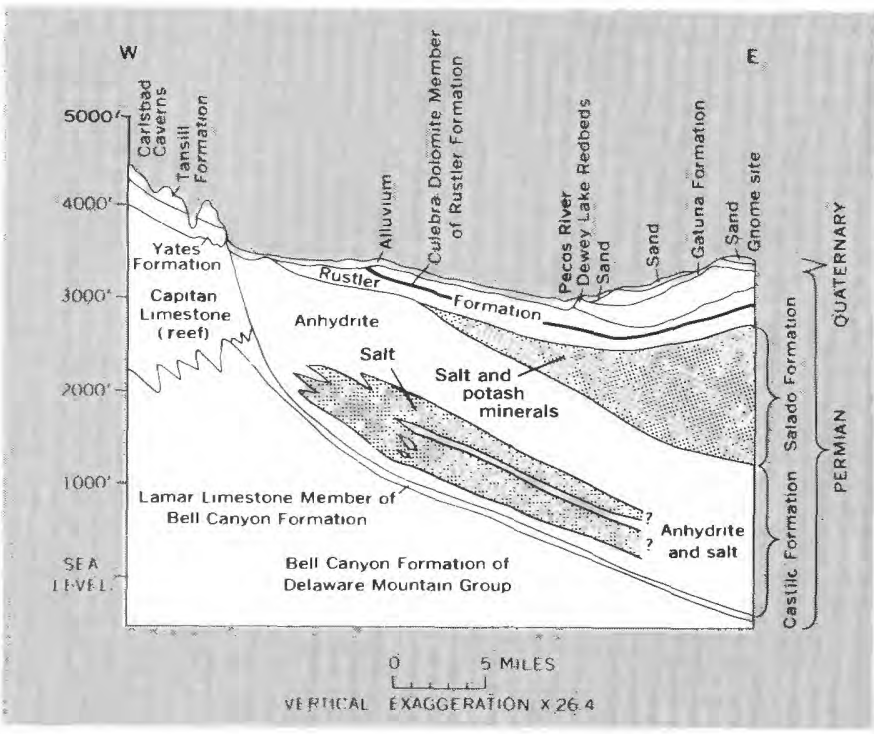

FIGURE 4.-Geologic section between Carlsbad Caverns National Park and the Project Gnome site. Modified from Cooper (1960).

solution of the evaporite rocks of the Permian System. No deeply buried faults are known. Locally in rocks overlying the salt of the Salado Formation, structural features are present which may be related to the hydration and chemical change of anhydrite to gypsum (Vine, 1960). Nash Draw is a prominent surface expression of evaporite solution. In the southern part of the area, solution of evaporites has created a deep trough which has been subsequently filled with sediments of Tertiary and Quaternary age to a thickness of more than 1,000 feet in some places (Maley and Huffington, 1953, p. 539).

Excavation of a 1,200-foot vertical access shaft 12 feet in diameter, begun on July 1, 1960, presented an unusual opportunity for inspection and study of the rocks beneath the surface at the Project Gnome site. Formations exposed in the shaft consisted of about 92 feet of sand, sandstone, and conglomerate of Holocene and Pleistocene (?) age; 202 feet of siltstone of the Dewey Lake Redbeds of Permian age; 357 feet of gypsum, anhydrite, siltstone, and dolomite of the Rustler Formation of Permian age; 58 feet of claystone, siltstone, and anhydrite and gypsum breccia (residual material and solution breccia derived from rocks of the Rustler and Salado Formations) ; and 493 feet of salt containing thin layers of claystone, polyhalite, and anhydrite of

TABLE 1.-Generalized section of the rocks exposed in the Project Gnome area

\begin{tabular}{|c|c|c|c|c|c|c|c|}
\hline System & Serles & Group & Formation & Member & $\begin{array}{l}\text { Thick- } \\
\text { ness } \\
\text { (feet) }\end{array}$ & Physical character & Water-bearing propertles \\
\hline \multirow{5}{*}{ Quaternary } & \multirow{4}{*}{ Holocene } & & $\begin{array}{l}\text { Windblown } \\
\text { sand }\end{array}$ & & $0-100 \pm$ & Very fine to coarse reddish-brown sand & Yields no water to wells in Project Gnome area. \\
\hline & & & $\begin{array}{l}\text { Playa lake } \\
\text { deposits }\end{array}$ & & $?$ & Silt, quartz sand, and gypsum sand............ & $\begin{array}{l}\text { May yleld small quantities of water in large playa } \\
\text { lakes. }\end{array}$ \\
\hline & & & Alluvium & & $0-200 \pm$ & Silt, sand, gravel, and conglomerate............ & $\begin{array}{l}\text { Yields large quantities of water to wells near } \mathrm{Pe}- \\
\text { cos Rlver. }\end{array}$ \\
\hline & & & Caliche & & $0-30 \pm$ & $\begin{array}{l}\text { Limestone with included sand grains and rock } \\
\text { fragments. }\end{array}$ & Ylelds no water to wells in Project Gnome area. \\
\hline & $\begin{array}{l}\text { Pleisto- } \\
\text { cene (?) }\end{array}$ & & Gatuna & & $0-200 \pm$ & $\begin{array}{l}\text { Clay, silt, sand, gravel, and conglomerate. Red- } \\
\text { dish orange to gray. }\end{array}$ & $\begin{array}{l}\text { Yields small quantities of water to wells in parts } \\
\text { of Project Gnome area. }\end{array}$ \\
\hline Tertiary & Plíocene & & Ogallala & & $0-300 \pm$ & Silt, sand, and gravel. & $\begin{array}{l}\text { Ylelds fairly large quantitles of water to wells } \\
\text { north and east of Project Cnnome area. }\end{array}$ \\
\hline \multirow{2}{*}{ Triassic } & \multirow{2}{*}{ Upper } & \multirow{2}{*}{ Dockum } & $\begin{array}{l}\text { Upper red } \\
\text { beds }\end{array}$ & & $\stackrel{0-}{1,000 \pm}$ & Shale, siltstone, and sandstone. Red to brown... & $\begin{array}{l}\text { Yields small quantities of water to wells in some } \\
\text { localitles. }\end{array}$ \\
\hline & & & $\begin{array}{l}\text { Santa Rosa } \\
\text { Sandstone }\end{array}$ & & $0-300 \pm$ & $\begin{array}{l}\text { Sandstone, conglomeratic, interbedded with clay- } \\
\text { stone. Red to gray. }\end{array}$ & $\begin{array}{l}\text { Yields small quantities of water to wells in places } \\
\text { in eastern part of Project Gnome area. }\end{array}$ \\
\hline \multirow{7}{*}{ Permian } & \multirow{7}{*}{ Ochos } & & $\begin{array}{l}\text { Dewey } \\
\text { Lake Red- } \\
\text { beds }\end{array}$ & & $0-350 \pm$ & $\begin{array}{l}\text { Siltstone, sandy shale, shale, and sandstone. Red } \\
\text { to reddish orange with greenish-gray reduction } \\
\text { spots. }\end{array}$ & $\begin{array}{l}\text { Not known to yleld water to wells in Project } \\
\text { Gnome area. }\end{array}$ \\
\hline & & & \multirow{5}{*}{ Rustler } & $\begin{array}{l}\text { Forty- } \\
\text { niner }\end{array}$ & $0-80 \pm$ & $\begin{array}{l}\text { Gypsum, gray to white. Stitstone, claystone, and } \\
\text { sandstone, reddish-brown with greenish-gray } \\
\text { reduction spots. }\end{array}$ & $\begin{array}{l}\text { May yleld water to wells in parts of the Project } \\
\text { Gnome area. }\end{array}$ \\
\hline & & & & $\begin{array}{l}\text { Magenta } \\
\text { Dolomite }\end{array}$ & $0-30 \pm$ & $\begin{array}{l}\text { Dolomite, gray to magenta. Anhydrite and sele- } \\
\text { nite. }\end{array}$ & $\begin{array}{l}\text { Yields small quantities of water to wells in Nash } \\
\text { Draw. }\end{array}$ \\
\hline & & & & Tamarisk & $0-120 \pm$ & $\begin{array}{l}\text { Gypsum, gray to red. Siltstone and claystone, } \\
\text { reddish-brown. }\end{array}$ & $\begin{array}{l}\text { May yleld water to wells in parts of the Project } \\
\text { Gnome area. }\end{array}$ \\
\hline & & & & $\begin{array}{c}\text { Culebra } \\
\text { Dolomite }\end{array}$ & $10-40 \pm$ & Dolomite, grayish-white & Principal aquifer at site of Project Gnome. \\
\hline & & & & Lower & $90-180 \pm$ & $\begin{array}{l}\text { Sandstone, claystone, and gypsum. Reddish } \\
\text { brown to light gray. }\end{array}$ & $\begin{array}{l}\text { May yield water to wells in parts of the Project } \\
\text { Gnome area. }\end{array}$ \\
\hline & & & Castile & & $0-1,600 \pm$ & Gypsum and siltstone. Gray to red............... & $\begin{array}{l}\text { Not known to yield water to wells in Project } \\
\text { Gnome area. }\end{array}$ \\
\hline
\end{tabular}


the Salado Formation of Permian age (Gard, 1968, p. $5)$. The top of the massive salt was 709 feet beneath the land surface. A generalized columnar section of rocks beneath the surface at the Project Gnome site is given in figure 5 .

The nuclear device was detonated in the Salado Formation, at a depth of about 1,200 feet, in a chamber at the end of a drift extending about 1,100 feet $N$. $50^{\circ} \mathrm{E}$. from the bottom of the shaft. Thus, the rock cover over the detonation point consisted of about 500 feet of massive salt and about 700 feet of various other types of sedimentary rocks.

\section{CASTILE FORMATION}

The Castile Formation is composed principally of anhydrite and calcite-banded anhydrite. Other constituents are salt and minor amounts of limestone, clastics, and other evaporites. The formation is confined to the Delaware basin. To the northwest of the basin it thins and pinches out against the reef of Capitan Limestone. To the southeast it thickens to more than 2,100 feet in west-central Ward County, Tex. (Adams, 1944, p. 1604).

Extensive outcrops of the Castile Formation are present in the western part of the Delaware basin just southwest of the Project Gnome area, and two small patches of the formation crop out along the west side of the area. The formation, where exposed, contains no salt, and the anhydrite has been hydrated by ground water to gypsum, probably to depths of several hundred feet.

Water is yielded to stock and domestic wells in the outcrop area of the Castile Formation. No wells are known to obtain water from the Castile within the Project Gnome area, and it is not known if the formation contains water beneath the project site.

\section{SALADO FORMATION}

The Salado Formation is mostly salt, although it contains extensive deposits of potash minerals which are mined at many localities and refined for potash fertilizers. Salt comprises more than 75 percent of the formation except where the section has been thinned by removal of part of the salt by ground-water solution. The remainder of the formation consists of potassium minerals and minor amounts of sandstone, siltstone, shale, anhydrite, and dolomite. The Salado does not crop out near the Project Gnome site.

Circulating ground water reportedly has not been found in the formation in the potash mines or in any of the numerous drill holes scattered throughout the area. Small pockets of entrapped water have, however, occasionally been found during mining. At various depths in the formation, drill holes have penetrated pockets of nonflammable gas or air which are often under sufficient pressure to cause geysering or blowouts of drilling fluid to heights of several tens of feet above the land surface.

West of the Pecos River most of the salt in the Salado Formation has been removed by solution. In the northwestern part of the Project Gnome area, over the buried reef of Capitan Limestone, the salt is absent, and beneath an area of nearly 100 square miles in the south-central part, the salt is thin or absent (Cooper, 1962, fig. 5). Within Nash Draw, solution has removed, and is presently removing, salt from the uppermost part of the formation.

In the Project Gnome area the contact between the Salado Formation and the overlying Rustler Formation is marked at many places by a layer of solution breccia and residual material. This layer consists of broken and collapsed layers of gypsum separated by irregular seams and masses of reddish-brown and gray clay and silt. The material is derived from rocks of both formations.

While many geologists designate this residual layer as the leached member of the Salado Formation (Gard, 1968 , p. 7), others assign it to the Rustler Formation (Hale and others, 1954, p. 19). This discrepancy results partly because the Rustler Formation to the east is reported to contain some beds of salt, and partly because the leached zone of the Salado Formation cannot be clearly distinguished from the lower member of the Rustler Formation in either drill cuttings or geophysical logs. Most of the data used in this report to interpret subsurface conditions in the Project Gnome area and at the project site were obtained from records of drilled wells. Thus, in this report the top of the uppermost thick salt bed is considered to be the top of the Salado Formation, and the residual layer is considered to be a part of the lower member of the Rustler Formation.

\section{RUSTLER FORMATION}

The Rustler Formation is mostly anhydrite (commonly altered to gypsum) but includes some gray carbonaceous sandstone and red siltstone composed of fine quartz grains. Dolomitic limestone and some red and gray shale are also present in the formation.

All members of the Rustler Formation crop out in the Project Gnome area. The exposures are in the western part near Nash Draw and southward along both sides of the Pecos River.

The structure of the Rustler Formation is mildly undulating. Solution and collapse have commonly affected the formation to depths of $200-300$ feet, and locally to greater depths. Generally the dolomite members of the 


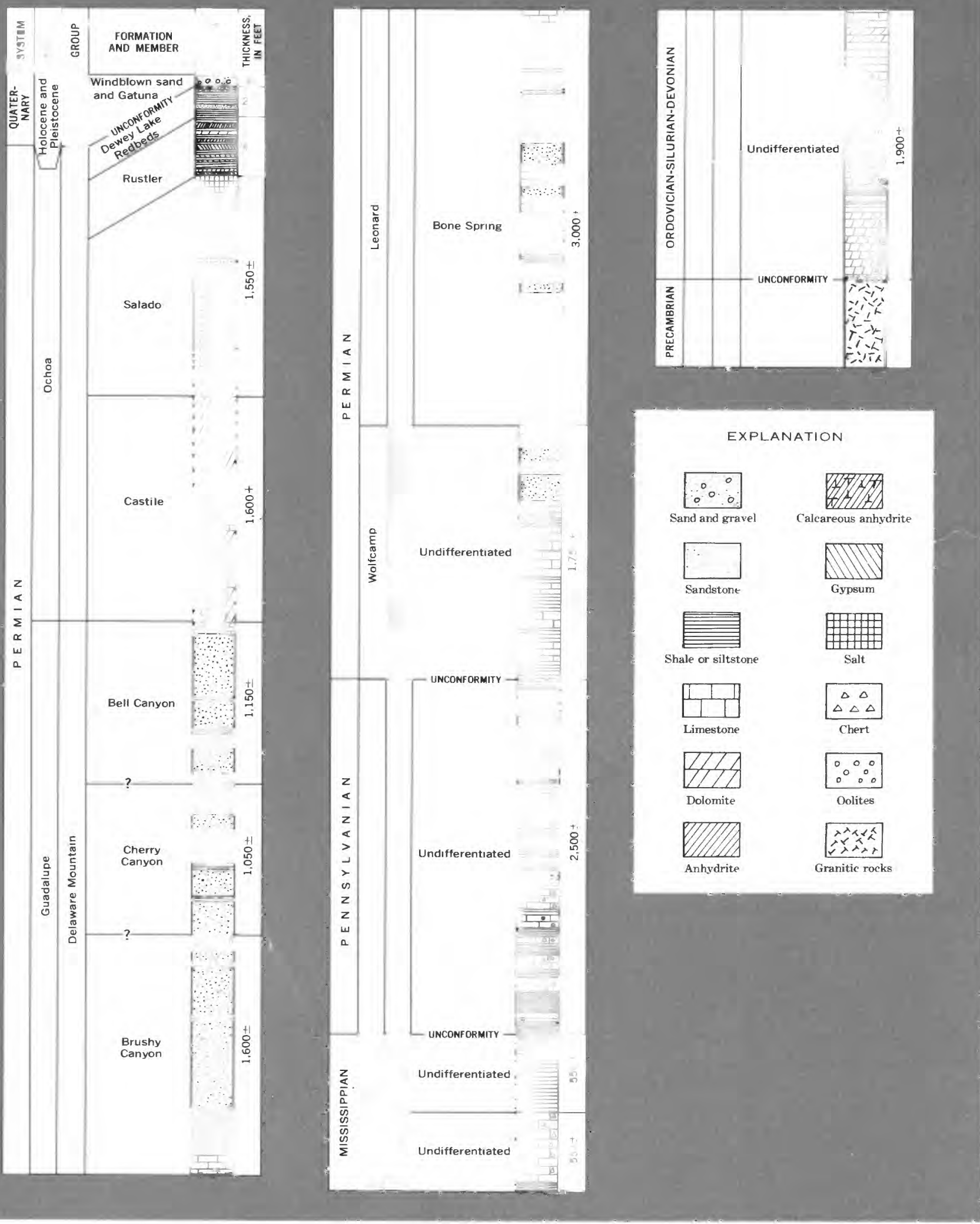

Figure 5.-Generalized stratigraphic section at Project Gnome site. 
formation are less affected by solution than the gypsum member and are present throughout most of the area. At the Project Gnome site the two dolomite members (table 1) are generally separated more than 100 feet by the Tamarisk Member. In some localities in the Nash Draw area, solution and collapse removed all the Tamarisk between them, and the Magenta Dolomite Member rests directly upon the Culebra Dolomite Member.

The Culebra Dolomite Member has been identified in many hundreds of drill holes. Its lithologic character is different from that of all other rocks in the area, and as a result it is an excellent subsurface marker bed. This member is the principal aquifer at the Project Gnome site and, in addition, yields water to wells in the western half of the area investigated (fig. 1).

\section{DEWEY LAKE REDBEDS}

The Dewey Lake Redbeds crop out at several places near the Project Gnome site, and thick sections of these beds are exposed about 15 miles north of the site. These red beds are composed of a series of fine sandy to earthy red beds and thin beds of sandstone dotted with green reduction spots and generally irregularly veined with thin secondary selenite fillings. The color and texture of the beds are nearly uniform. The Dewey Lake Redbeds are not known to yield water to wells. Small bodies of perched water possibly could be present where beds of standstone occur within the formation.

\section{TRIASSIC FORMATIONS}

The Santa Rosa Sandstone of Triassic age, which unconformably overlies the Dewey Lake Redbeds, is present a few miles to the east of the Project Gnome site. In Iea County, a series of red shale, siltstone, and sandstone beds, probably the Chinle Formation of the Dockum Group, overlies the Santa Rosa. The Santa Rosa and beds of sandstone within the overlying red beds yield water to wells.

\section{TERTIARY FORMATIONS}

Northeast and southeast of the Project Gnome site, in Lea County, small outcrops of the Ogallala Formation of late Tertiary (Pliocene) age are present, but the formation does not extend westward as far as the project site. The Ogallala yields water to wells in its outcrop area.

\section{QUATERNARY FORMATIONS}

The Gatuna Formation of Pleistocene(?) age is the oldest formation of Quaternary age in the Project Gnome area. The formation crops out at several places and is present at the project site. The formation is composed of poorly consolidated sand, silt, and clay with minor amounts of medium- to coarse-grained sandstone and pebble conglomerate. Locally, the Gatuna yields small supplies of water to wells. The water is perched in permeable sand lenses of limited areal extent.

Caliche, alluvium, playa lake deposits, and windblown sand are present at or near the Project Gnome site. The caliche forms a cap over older formations in much of the area investigated. It is mostly covered with windblown sand but crops out at many places. At the project site a layer of friable caliche is present from about 7 to 10 feet beneath the land surface, and minor amounts of caliche are present within the unconsolidated sand which overlies the Gatuna Formation. About 7 feet of dune sand is present at the site, and in the immediate vicinity there are conspicuous dunes several tens of feet thick.

Alluvial sand and silt, locally conglomeratic, is present on some gentle slopes and in valley bottoms in the area investigated. The most extensive deposits are on the west side of the Pecos River north of Malaga. Scattered small patches occur along both sides of the river. Near the river and west of the river, the alluvium yields several hundred gallons per minute to wells.

Small playas occur mainly in the vicinity of Nash Draw. The floors of the playas consist of silt, siliceous sand, and gypsum sand deposited in shallow and intermittent lakes. Laguna Grande de la Sal is a shallow lake that occupies a part of a large playa in Nash Draw. The lake has no surface outlet and contains a brine solution that has been concentrated by evaporation. Since 1932, Laguna Grande de la Sal has been used for disposal of waste products from the potash refinery of United States Borax and Chemical Co. near the west side of the lake.

\section{GROUND WATER}

Figure 6 shows locations of water-bearing formations in the Project Gnome area.

The Culebra Dolomite Member of the Rustler Formation is the most widespread aquifer in the Project Gnome area. Yields of water from this aquifer vary considerably from place to place and are dependent upon the size and number of openings and fractures in the dolomite; these openings and fractures in turn are apparently related to the thickness of the overlying formations. In the upper part of Nash Draw the dolomite is near the surface and has been subjected to extensive solution weathering. Wells in this area are reported to yield as much as $700 \mathrm{gpm}$ (gallons per minute). East of Nash Draw, where the dolomite is covered by several hundred feet of younger rocks, yields of wells are generally not large. Water in the Culebra 
GEOHYDROLOGY OF PROJECT GNOME SITE, NEW MEXICO

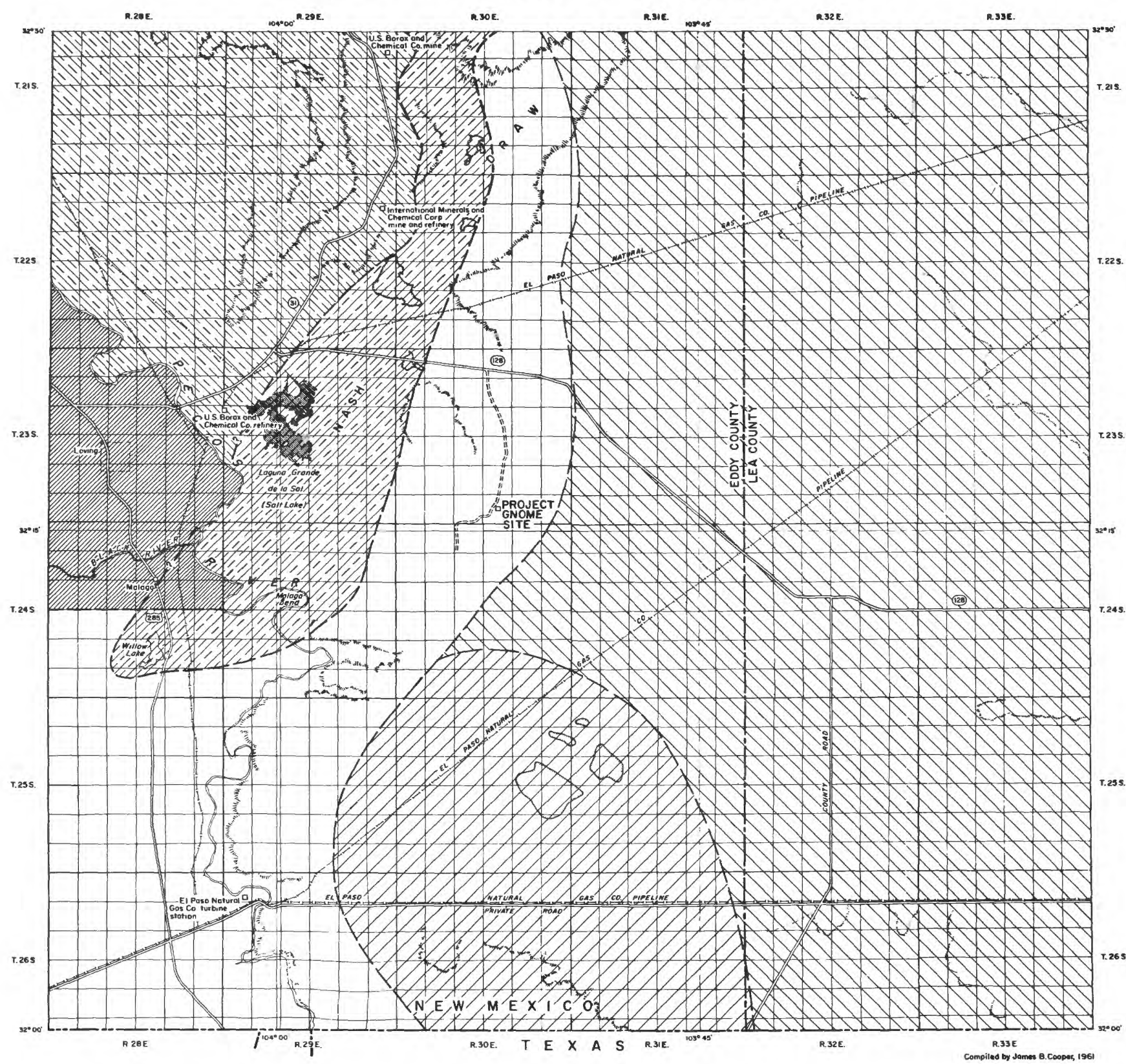

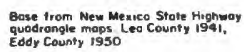

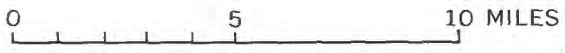

EXPLANATION

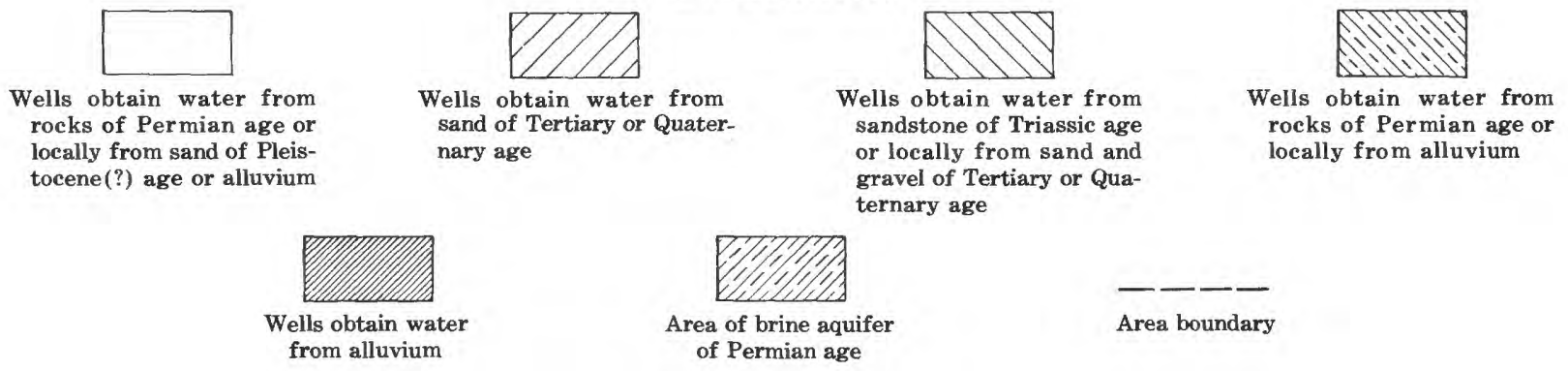

Figure 6. -General distribution of water-bearing formations in the Project Gnome area. 
is under artesian pressure, except beneath the alluvium west of the Pecos River and in its outcrop area, where the water in the member is unconfined. The member apparently is recharged in the northwestern part of the area, where it is overlain by saturated sandstones of Triassic age. East of the Pecos River the aquifer discharges into Nash Draw or into the alluvium which adjoins the river.

The Santa Rosa Sandstone is the principal aquifer in Lea County, in the eastern part of the Project Gnome area. In places where the Santa Rosa is overlain by red beds, probably the Chinle Formation, wells commonly are completed in beds of sandstone of these younger strata. In the upper part of the Triassic section the water is probably under water-table conditions or, in places, under perched-water conditions. Water in the Santa Rosa is under artesian pressure where it is covered by younger formations.

Wells in the south-central part of the area obtain water from beds of sand, each as much as 50 feet thick and separated by somewhat thicker beds of clay, within the deep depression formed by solution of evaporites of Permian age. Most of these deposits probably are of Quaternary age, but some may be of later Tertiary age. The total thickness of saturated deposits is about 800 feet. Yields of several hundred gallons per minute are obtained from wells finished in these deposits. The primary source of recharge to these beds of sand probably is local precipitation that infiltrates from large sinkholes and other surface depressions.

The Gatuna Formation occurs erratically and contains no continuous saturated zone. Water in the formation is from local precipitation and is perched over relatively impermeable beds of the Dewey Lake Redbeds. However, at two locations within the study area, beds of sand and conglomerate in the formation yield water to wells. Wells penetrate less than 20 feet of saturated material, and continuous yields of only a few gallons per minute can be expected.

West of the Pecos River and north of Malaga, water is obtained from many wells in the alluvium. Most of the wells yield several hundred gallons per minute and are used for irrigation. Water in the alluvium is under water-table conditions and is hydraulically connected with water in the underlying Rustler Formation. Recharge to the alluvium west of the river is from precipitation and from Pecos River water that enters the alluvium from leaking canals and irrigated fields.

In the Malaga Bend area and west and north of Laguna Grande de la Sal, alluvium extends as much as 3 miles east of the river. Two wells in sec. 14, T. $23 \mathrm{~S}$., R. 28 E., are reported by the owner to yield from 1,500 to $3,000 \mathrm{gpm}$ each. Recharge to the alluvium east of the river is from precipitation, inflow of ground water from older formations to the east, excess irrigation water, and the river itself. On the uplands east of the river only a few wells are finished in alluvium.

In Nash Draw and eastward to near the Project Gnome site, an aquifer (the residual layer of the Rustler Formation) overlying the salt contains a brine solution. This aquifer discharges into the Pecos River, and its discharge is a major factor in the salt contamination of the river water. No water is known to occur in the project area below the top of the salt of the Salado Formation.

\section{AVAILABILITY AND UTILIZATION}

Wells within 15 miles of the Project Gnome site obtain water at depths ranging from 30 to 800 feet from various formations. The depth to water below the land surface ranges from a few feet to about 500 feet. Ground water is generally under artesian pressure, and the general direction of movement is toward the Pecos River. Plate 1 shows the location of wells and the general direction of ground-water movement in the geologic formations in the Project Gnome area.

Ground water in the Project Gnome area east of the Pecos River is used for domestic, stock, industrial, irrigation, and construction supplies. Most of the wells used for domestic supplies also furnish water for stock. Most ranches also have several stock wells on land used for grazing. The El Paso Natural Gas Co., operates two wells to supply water for its turbine station.

Many domestic, stock, and irrigation wells are in use on the west side of the Pecos River. The irrigation wells, most of which are north of Malaga, supply water that is used primarily to supplement the river water used for irrigation.

At the time of the nuclear experiment, there were 10 privately owned water wells within a 5-mile radius of the test site. These wells were used primarily for watering livestock; however, the water from two wells was also used for human consumption.

\section{AQUIFER CHARACTERISTICS AT AND NEAR PROJECT SITE}

At the Project Gnome access shaft and in the Geological Survey test holes that were constructed on the site (within sec. 34, T. 23 S., R. 30 E.), water was found only in the Culebra Dolomite Member of the Rustler Formation (fig. 7). There, it is in fractures in the dolomite and is confined by gypsum and anhydrite beds above and by clay and anhydrite beds below. Average thickness of the aquifer is 30 feet, and the top is at a depth of about 500 feet. Water in the aquifer is under artesian pressure and near the access shaft rises to a level about 75 feet 
above the dolomite. Water-level data from the vicinity of the project site ( $\mathrm{pl} .1$ ) indicate that the potentiometric surface slopes generally westward about 12 to 15 feet per mile. Measurements in test holes at the project site do not indicate this amount of slope. Differences in altitude of the static water level in test hole 1 and test hole 4 (less than one-half mile apart) are 1 foot or less. The direction of movement of water at the site is westward, although both southwesterward and northwestward components of movement occur within short distances.

Blocks of dolomite from the Culebra Dolomite Member were obtained during the excavation of the access shaft. These were analyzed for porosity by the U.S. Geological Survey. One sample, from a depth of 505 feet, had a total porosity of 14.4 percent and an effective porosity of 7.8 percent. A second sample, from 515 feet, had total porosity of 13.7 percent and effective porosity of 11.1 percent. An average value for effective porosity of these samples appears to be about 10 percent.

During excavation of the shaft, small-diameter holes were drilled into the Culebra Dolomite Member, and

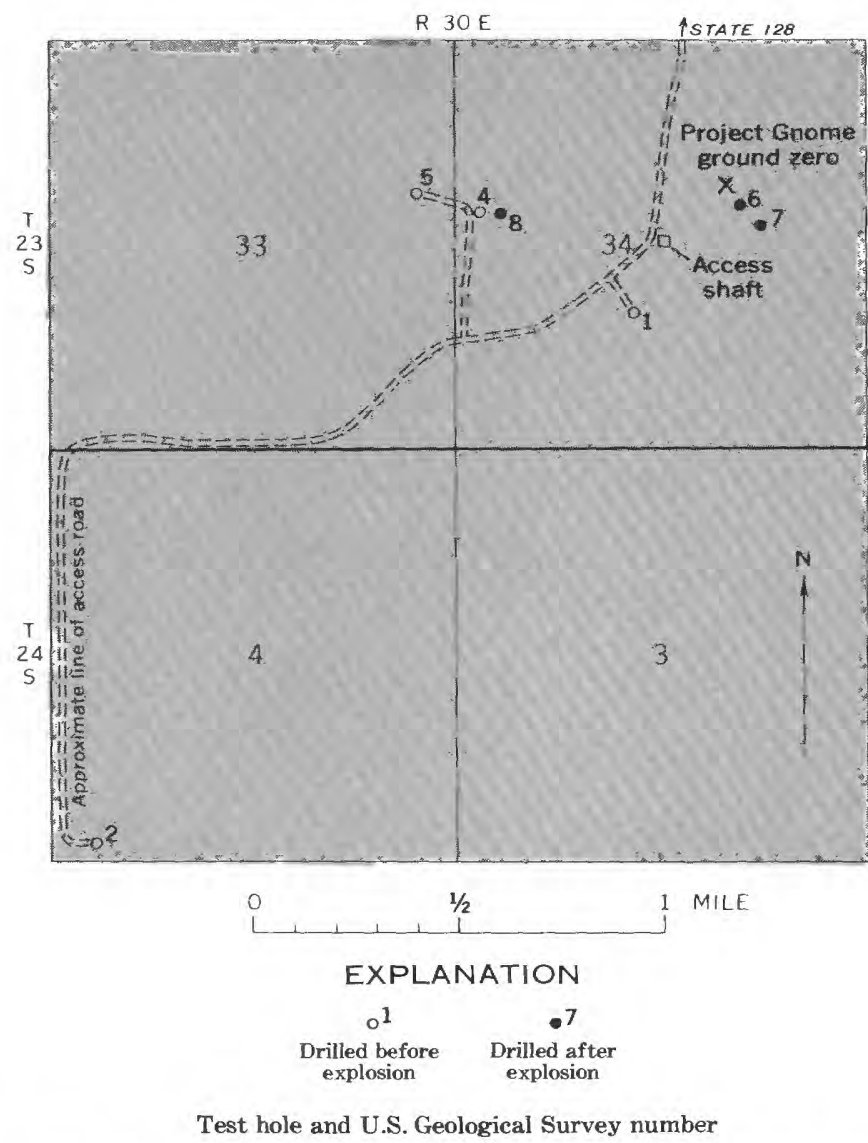

Figure 7.-Location of U.S. Geological Survey test holes near the Project Gnome site. cement and chemical grout were pumped into the formation to reduce water inflow into the shaft.

\section{TRANSMISSIVITY AND STORAGE COEFFICIENT}

The transmissivity, $T$, quantitatively describes the ability of the aquifer to transmit water. It is expressed as the rate of flow of water, in gallons per day, at the prevailing water temperature, through a vertical strip of the aquifer 1 foot wide extending the full saturated height of the aquifer under a hydraulic gradient of 100 percent.

The storage coefficient, $S$, of an aquifer is the volume of water the aquifer releases from or takes into storage per unit surface area of the aquifer per unit change in the component of head normal to that surface (Ferris and others, 1962, p. 74).

The data obtained during the pumping test of March 16 and 17,1963 , were plotted and interpreted according to the Theis nonequilibrium formula (Ferris and others, 1962, p. 92). Average values of $3,500 \mathrm{gpd}$ per $\mathrm{ft}$ (gallons per day per foot) for the transmissivity and $2 \times 10^{-5}$ for the storage coefficient were determined for the Culebra Dolomite Member at the Project Gnome site.

The transmissivity obtained for this aquifer test is somewhat less than that calculated from a similar test made in 1960 (4,000 gpd per fit, Cooper, 1962, p. 37). However, these values are of the same order of magnitude, and the difference is not great enough to necessitate changes in estimates of hydraulic conductivity and the rate of water movement in the aquifer.

The rate of movement, or the velocity, $V$, of water in an aquifer is directly proportional to the slope of the potentiometric surface, $I$, and to the hydraulic conductivity of the materials, $K$; it is inversely proportional to the porosity, $\theta$, of the materials. The velocity is expressed by the formula $V=K I / \theta$.

A calculation of the average rate of movement of water through the Culebra Dolomite Member in the vicinity of the Project Gnome site, using $K=116.7 \mathrm{gpd}$ per square foot, $I=4.2 \times 10^{-4}$, and $\theta=0.10$, results in a figure of about one-half foot per day. Because the calculation is based on average hydraulic conductivity and porosity, the velocity may be more or less than 1 foot per day in some zones within the aquifer.

\section{AQUIFER YIELD}

Values obtained for the transmissivity and storage coefficien't of the Culebra Dolomite Member are extremely small. These data indicate that a well pumping only $100 \mathrm{gpm}$ will create large drawdowns in the well itself, and that the cone of depression will extend over a large area. 


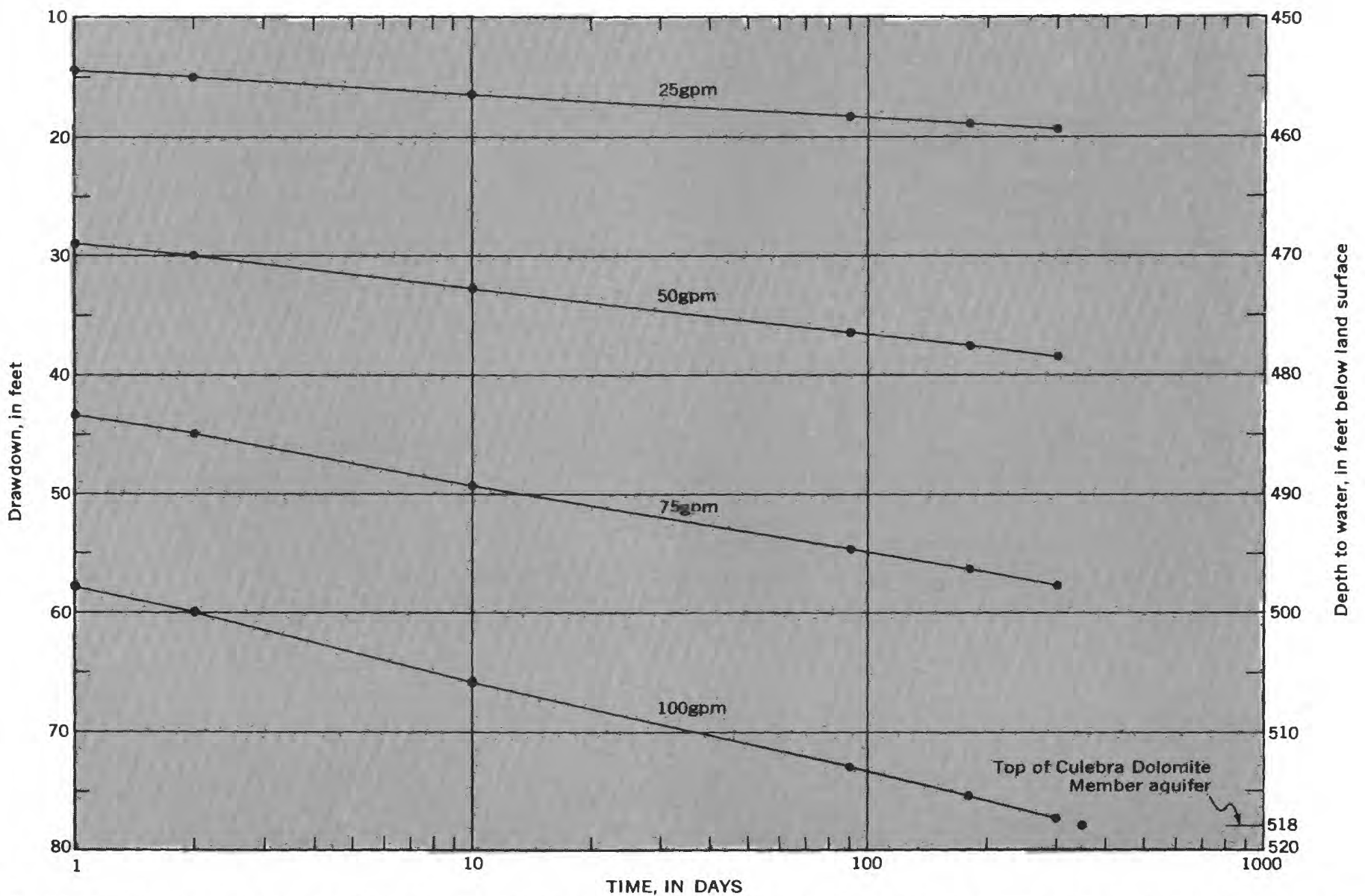

Figure 8.-Calculated time-drawdown plot of water level in U.S. Geological Survey test hole 1, when pumped continuously, at selected rates, Project Gnome site.

Figure 8 shows the drawdown of water level at selected pumping rates that could be expected in a well at the Project Gnome site where aquifer characteristics are similar to those determined in Geological Survey test hole 1. (For a description of the aquifer test made in test hole 1, see section on "Testing.") These calculations are for a well pumping continuously. If pumping is not continuous and the water level is allowed to recover, higher pumping rates would be possible. Moreover, the calculations do not take into account the possibility that recharge boundaries might be intercepted during long pumping periods, which would make possible higher pumping rates, or conversely, impermeable boundaries might be intercepted, which would make possible lower pumping rates.

The maximum expected yields, at various pumping rates of the Culebra Dolomite Member at the Project Gnome site, as shown in figure 8, are for a single pumped well. However, little, if any, additional water could be obtained, over a period of more than a few days, by continuous pumping simultaneously from two or more closely spaced wells. For example, pumping $100 \mathrm{gpm}$ simultaneously from each of two wells spaced as far as 3,700 feet apart would seriously lower the water level in both wells after a period of about 10 days.

\section{TEST HOLES AT AND NEAR PROJECT SITE}

The most detailed water-level observations prior to the detonation at the Project Gnome site were made in four test holes drilled specifically to observe water levels and to obtain information on aquifer characteristics. Additional data were obtained from observations made in the access shaft and from holes drilled for another purposes.

Geologic and hydrologic studies made to evaluate the effect of the nuclear explosion on the aquifer at the project site have in part been integrated with studies made by other geologists of the U.S. Geological Survey and other investigative agencies. One such study was made to determine the shock-induced solid-state characteristics of the rock types at the site. The two drill holes from which rock cores were obtained for this study were completed as a ground-water test hole. A hole drilled at the site to obtain rock cores for use in seismic studies by 
Roland F. Beers, Inc., was also completed as a groundwater test hole.

This report contains data on the completion of these three holes as ground-water test holes. Results of the study of the rock cores are not included. Locations of all seven test holes are shown in figure 7.

\section{CONSTRUCTION}

U.S. Geological Survey test holes 1 and 2 were drilled in August and September 1960 for the purpose of testing the occurrence of water in rocks above the top of the salt of the Salado Formation.

Test hole 1 (993 ft south and $393 \mathrm{ft}$ west of the access shaft) was drilled to a depth of 722 feet. The Culebra Dolomite Member of the Rustler Formation, between the depths of 517 and 549 feet, contributed the only water to the hole. After drilling to 722 feet the hole was completed by plugging it with cement from 566 to 722 feet and perforating the casing opposite the aquifer. The water in the hole rose to about 440 feet below land surface (altitude of $2,985 \mathrm{ft}$ above mean sea level). A water sample was collected from the hole for chemical analysis.

In test hole 2 (about 2 miles southwest of the access shaft) the Culebra Dolomite Member was dry, and the only water was in the section of rocks between the Culebra and the top of the salt of the Salado Formation. The hole was drilled to a depth of 607 feet and completed by slotting the casing opposite the water-bearing formations, from 452 to 582 feet below land surface. The water in the hole rose to about 394 feet below land surface (altitude of $3,008 \mathrm{ft}$ above mean sea level). A water sample was collected from the hole for chemical analysis.

Although a site was selected for test hole 3, a hole was not drilled. Test holes 4 and 5 were completed in November and December 1961. These two holes are downgradient from the detonation point, in the general direction of water movement, and were drilled for observing water levels and other hydrologic conditions just before, during, and after the explosion.

In test hole 4 (394 ft north and $2,375 \mathrm{ft}$ west of the access shaft), water was found only in the Culebra Dolomite Member. The hole was drilled to a depth of 511 feet, and it penetrated the Culebra Dolomite Member from 472 to 506 feet. It was completed with casing to the top of the dolomite. Water in the hole rose to about 429 feet below land surface (altitude of 2,984 ft above mean sea level). A water sample was collected from the hole for chemical analysis.

In test hole $5(633 \mathrm{ft}$ north and $3,175 \mathrm{ft}$ west of the access shaft), water was found at depths of about 417 feet, in the Magenta Dolomite Member of the Rustler
Formation; at about 500 feet, in the Culebra Dolomite Member; and at about 685 feet, in the residual material of the Rustler and Salado Formations directly above the salt of the Salado Formation. The hole is constructed so that only the water in the lower aquifer, just above the salt, can enter the hole. This brine aquifer is only a few feet thick. Water in the hole rose to about 490 feet below land surface (altitude of 2,948 ft above mean sea level). A water sample was collected from the hole for chemical analysis.

Test holes 6 and 7 were drilled during the period from January 31 to March 30, 1962. They are approximately 150 feet and 500 feet, respectively, S. $40^{\circ} \mathrm{E}$. from ground zero of the detonation point. Upon completion of drilling and coring, the drill holes were used as ground-water test holes to observe water levels and to provide sampling points for water in the aquifer.

In test hole 6 , drilled to a depth of 1,489 feet, water was found only in the Culebra Dolomite Member. The hole was completed by plugging it with cement from 1,489 to 567.5 feet and by perforating the casing opposite the aquifer, between 498 and 532 feet. Water from the aquifer rose to about 417 feet below the land surface (altitude of $2,983 \mathrm{ft}$ above mean sea level).

In test hole 7, drilled to a depth of 1,507 feet, water was found only in the Culebra Dolomite Member. The hole was completed by plugging it with cement from 1,507 to 563 feet and by perforating the casing opposite the aquifer, between 514 and 545 feet. Water in the hole rose to about 420 feet below the land surface (altitude of $2,982 \mathrm{ft}$ above mean sea level).

Water samples were collected after several hours of bailing from both test holes 6 and 7. However, the analyses indicate that the water sampled was not representative of the water in the Culebra Dolomite Member but instead was either brackish water used in the drilling of the hole or a mixture of drilling water and water from the aquifer.

Test hole 8 (alternately identified as the Carlsbad Joint-Use well) was drilled in October 1962. Upon completion of drilling and coring, the drill hole was used as a ground-water test hole for making water-level observations. Test hole 8 is 125 feet due east of test hole 4 , and the two holes are hydraulically connected.

In test hole 8, drilled to a depth of 722 feet, water was found only in the Culebra Dolomite Member. The hole was completed by plugging it with cement from 722 to 495.5 feet and leaving it uncased opposite the aquifer, between 460 and 494 feet. Water in the hole rose to about 429 feet below the land surface (altitude of 2,981 ft above mean sea level). A water sample was collected from the hole for chemical analysis. 


\section{TESTING}

In December 1960, excavation work was stopped in the vertical access shaft at a depth of 460 feet, about 35 feet above the top of the Culebra Dolomite Member, and a water-sealing program was begun in the shaft to shut out water from the aquifer. Holes were drilled into the dolomite from the 460-foot level, and a cement and chemical grout mix was injected into the formation under pressure. The release of water and pressure through drill holes from the aquifer during the water-sealing program in the shaft and during the excavation of the dolomite section was recorded graphically on the recording gage installed in Geological Survey test hole 1. Water level in the test hole stood about 442 feet below land surface before the grout injection holes were drilled into the aquifer. On December 12 and 13, 1960, after the initial grout injection, several more holes were drilled into the aquifer, and tests were made by the excavation contractor to determine the amount of water flowing from the individual open holes in the shaft. The discharge of water into the shaft from any one hole during this test was reported not to exceed $30 \mathrm{gpm}$. The discharge of water from the holes into the shaft caused a total water-level decline of about 1 foot in test hole 1 . (See fig. 9A).

By February 10, 1961, the water level in test hole 1 had declined to about 444 feet. (See fig. 9B.) On February 10 , injection of grout behind the concrete shaft liner, against the Culebra Dolomite Member in the interval from 515 to 525 feet, reduced water leakage into the access shaft from about $13 \mathrm{gpm}$ to about $5 \mathrm{gpm}$. In response to this partial sealing of the aquifer, the water level in the observation well rose about 1 foot. An additional water-level rise of about half a foot was noted in the well on February 14, when the interval from 490 to 515 feet was grouted, and the leakage of water into the access shaft was reduced to minor seepage. After February 14, the water level in the aquifer gradually rose toward its normal level.

Water-level fluctuations were also observed in test hole 1 during bailing from test hole 4. (See fig. $9 C$.) On December 4, while mud was being bailed from test hole 4, the water level in test hole 1 temporarily declined about one-quarter of a foot. A water-bailing test in hole 4 on December 5, covering a period of 8 hours at a bailing rate of $20 \mathrm{gpm}$, caused a water-level decline of about 1 foot in test hole 1 .

The sensitivity of the aquifer to internal water-pressure changes was demonstrated by the fluctuations of water levels in test holes 1 and 4 as a result of the 30 gpm discharge into the access shaft. These data suggest that leakage of water out of, or into, the aquifer near the shot point in amounts of 5 to $15 \mathrm{gpm}$ would be noticeable on a recording gage installed in an observation well.

On March 16 and 17, 1963, a 24-hour pumping and water-level-recovery test was made in test hole 1 . The objective of this test was to make a comparison with the pumping-test data obtained in 1960 during the drilling of the test hole, and to refine data on the transmissivity and other characteristics of the Culebra Dolomite Member.

Test hole 1 was pumped at a nearly constant rate of $54 \mathrm{gpm}$ for a period of 24 hours with an electric-drive submersible pump. Many of the water-level drawdown measurements made in the pumped well were very erratic due to periodic caving of loose silt down the annular space behind the well casing, which temporarily caused clogging of the perforations in the casing opposite the aquifer. The source of the silt is a zone of weathered gypsum from 500 to 509 feet, about 9 feet above the top of the aquifer. These conditions affected only the pumping rates and the color of the discharged water in the pumped well and were not reflected in the measurements made in the two observation wells.

At the time of the 1960 pumping test in test hole 1, no observation wells were available in which drawdown measurements could be made to obtain data on the storage coefficient of the aquifer. During the pumping and recovery test in March 1963, observations of water level were made in test hole $6\left(1,960 \mathrm{ft} \mathrm{N} .40^{\circ} \mathrm{E}\right.$. from the pumped well) and in test hole $8\left(2,310 \mathrm{ft} \mathrm{N} .53^{\circ} \mathrm{W}\right.$. from the pumped well) (fig. 7).

At the end of the 24-hour pumping period in test hole 1 , the drawdown of water level in test hole 8 was 2.74 feet, and that in test hole 6 was 4.08 feet. The water levels in both observation holes and in the pumped hole returned to near normal during the recovery period of 24 hours. Data obtained from measurements of drawdown and recovery of water levels in the pumped well and, in particular, in the two observation wells were used to compute the transmissivity and the storage coefficient. These data were then used to compute the amount of water, at various pumping levels, that the aquifer would yield over an extended period of time. (See fig. 8).

\section{INITIAL INVESTIGATION OF WATER WELLS WITHIN 15 MILES OF PROJECT SITE}

During the hydrologic investigations from October 1958 through May 1959, all known wells, used or unused, on the east side of the Pecos River within 15 miles of the Project Gnome site were visited. At that time, water for domestic use for 12 installations was supplied by wells east of the Pecos River. These installations include several ranch headquarters, single 


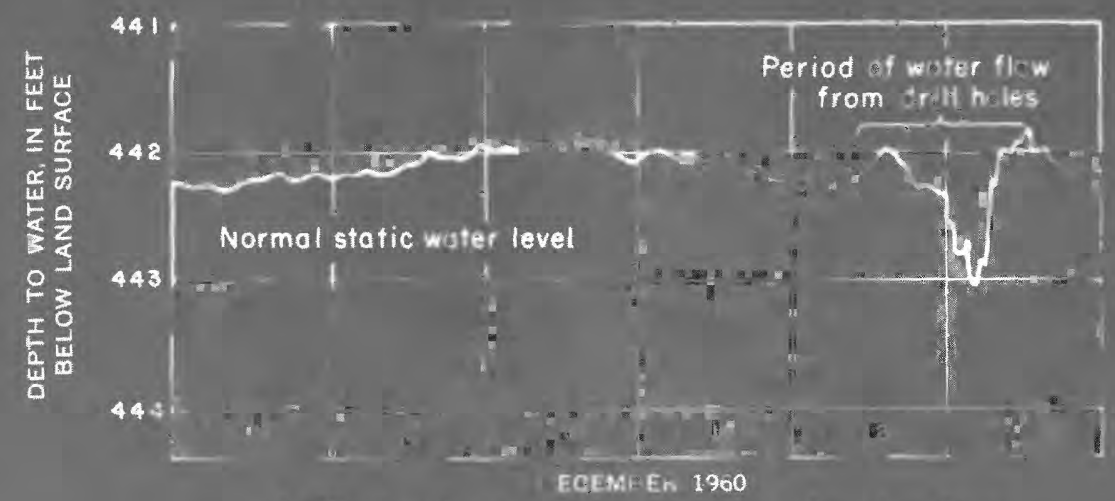

A. Fluctuations caused by release of water from ayuifer through grout drill holes in shaft.

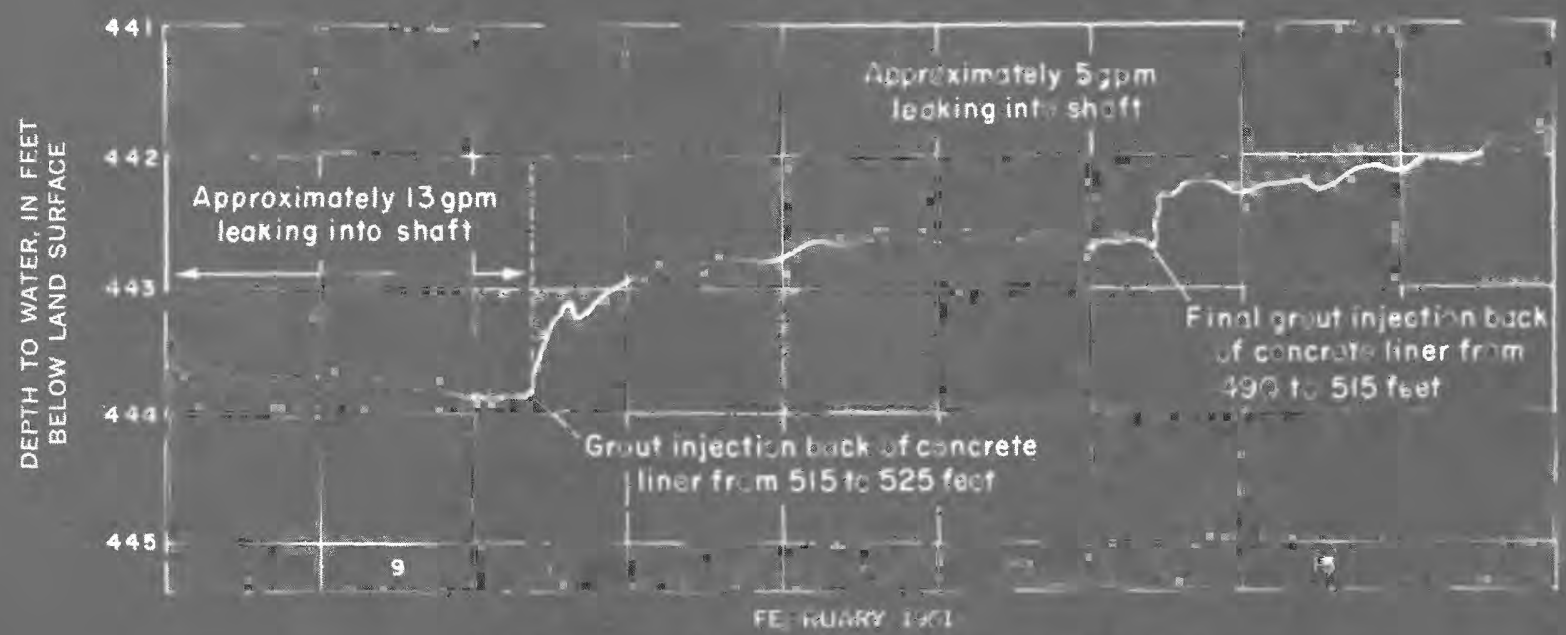

$B$. Fluctuations during final phase of water-sealing program in the Gnome shaft.

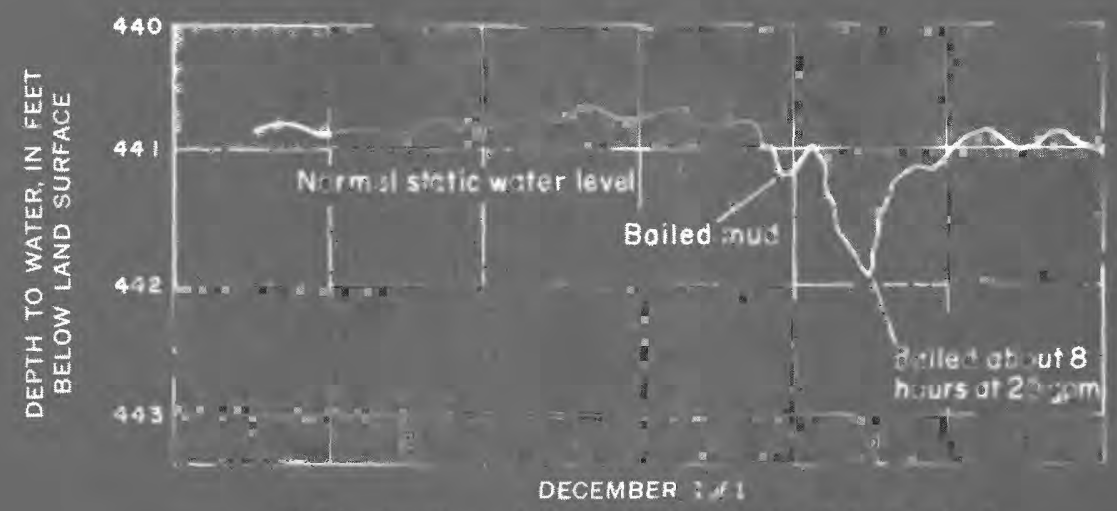

C. Fluctuations during bailing tests at test hole 4 .

Figure 9.-Fluctuation of water level in U.S. Geological Survey test hole 1 prior to the nuclear explosion, Project Gnome site. 
homes, and a group of houses at the Pecos turbine station of the El Paso Natural Gas Co.

To accurately determine the water level, well depth, capacity and condition of the pump, casing size, and other aspects of some wells in the proximity of the project site, pumping equipment was removed from the wells for insertion of measuring devices and for inspection of the pumps. Fifteen wells, including nine within a 5-mile radius of the test site, were investigated in this manner during March and April 1959. Specific data on the 67 wells investigated are given in table 2. Water samples were collected to determine the chemi-

TABLE 2.-Records of wells in the Project Gnome area

Owner or name: The owner of, or name used for, well at time of visit.

Altitude: From topographic maps.

Depths: Reported depths are given to the nearest foot; measured depths are given to the nearest 0.1 foot. $P$, pumping level.

Diameter: The diameter of the casing, or the mean diameter of the hole, if uncased. Measuring point: $\mathrm{Epb}$, edge of pump base; Ls, land surface; Tal, top of air-line flange Tap, top of access pipe; Tc, top of casing; Tcb, top of concrete block; Tcm, top of metal cover; Tpc, top of pipe clamp; Tpp, top of pump pipe; Twc, top of wood cover.
Geologic source: Prl; lower member of the Rustler; Prc; Culebra Dolomite Mernber of the Rustler; Prm; Magenta Dolomite Member of the Rustler; $\mathrm{Fr}$, rocks of Triassic age; QTu, undifferentiated rocks of probable Quaternary and Tertiary age; Qg; Ga-

tuna Formation; Qal, Quaternary alluvium.
Type of pump, power, and use: Pump designations: $T$, turbine; $\mathbf{L}$, cylinder; $\mathrm{N}$, none. Power designations: $W$, windmills; Ic, internal combustion; $N$, none; Use: $S$, stock $\mathrm{D}$, domestic; I, irrigation; In, industrial; $\mathrm{N}$, none.

Remarks: Name enclosed in quotation marks is local name of well. CA, chemical analysis available; $\mathrm{L}$, electric logs available; $\mathbf{R}$, reported information.

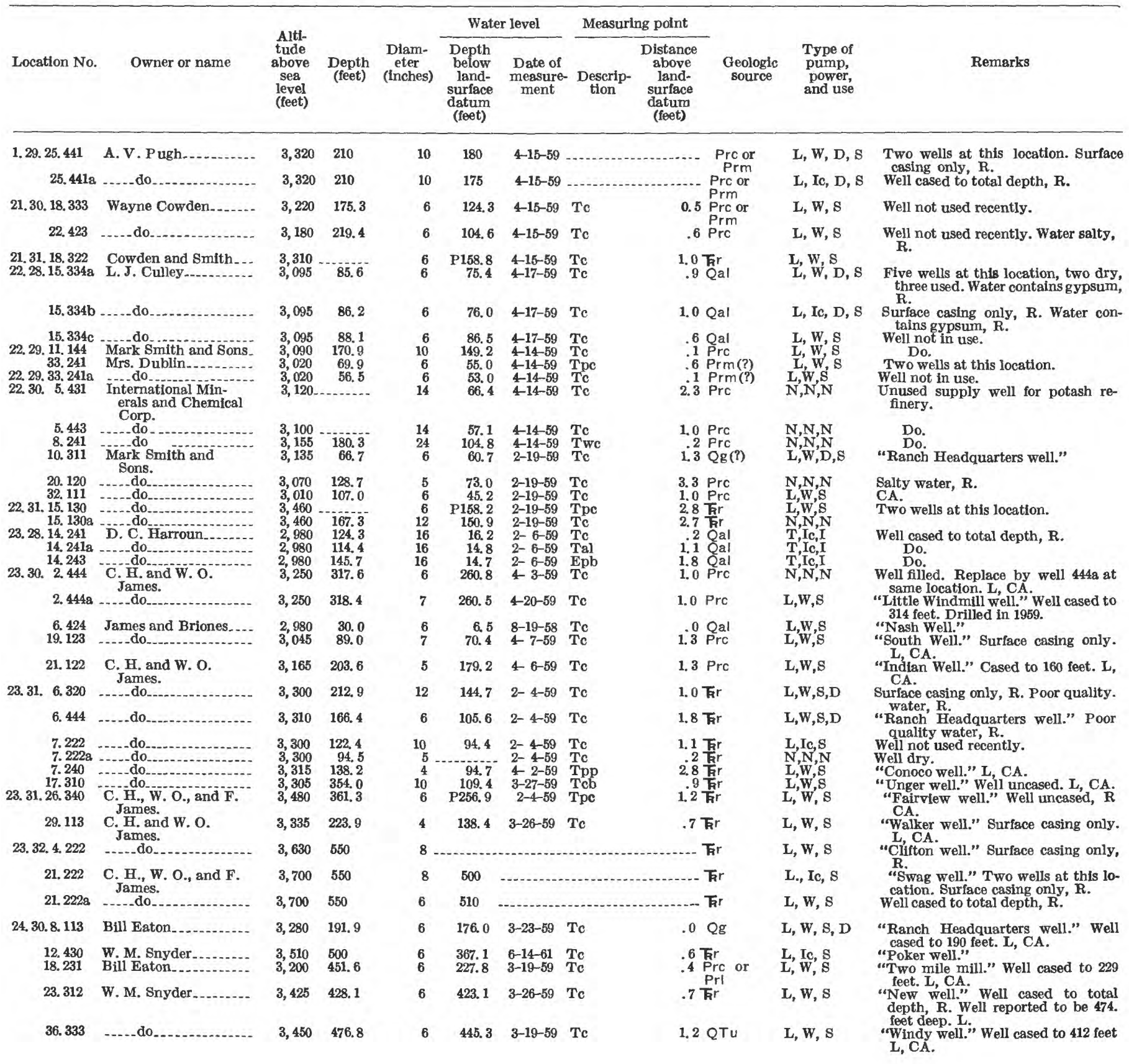


GEOHYDROLOGY OF PROJECT GNOME SITE, NEW MEXICO

TABLE 2.-Records of wells in the Project Gnome area-Continued

\begin{tabular}{|c|c|c|c|c|c|c|c|c|c|c|c|}
\hline \multirow[b]{2}{*}{ Location No. } & \multirow[b]{2}{*}{ Owner or name } & \multirow[b]{2}{*}{$\begin{array}{c}\text { Alti- } \\
\text { tude } \\
\text { above } \\
\text { sea } \\
\text { level } \\
\text { (feet) }\end{array}$} & \multirow[b]{2}{*}{$\begin{array}{c}\text { Depth } \\
\text { (feet) }\end{array}$} & \multirow[b]{2}{*}{$\begin{array}{l}\text { Diam- } \\
\text { eter } \\
\text { (inches) }\end{array}$} & \multicolumn{2}{|c|}{ Water level } & \multicolumn{2}{|c|}{ Measuring point } & \multirow[b]{2}{*}{$\begin{array}{l}\text { Geologic } \\
\text { source }\end{array}$} & \multirow[b]{2}{*}{$\begin{array}{l}\text { Type of } \\
\text { pump, } \\
\text { power, } \\
\text { and use }\end{array}$} & \multirow[b]{2}{*}{ Remarks } \\
\hline & & & & & $\begin{array}{c}\text { Depth } \\
\text { below } \\
\text { land- } \\
\text { surface } \\
\text { datum } \\
\text { (feet) }\end{array}$ & $\begin{array}{c}\text { Date of } \\
\text { measure- } \\
\text { ment }\end{array}$ & $\begin{array}{l}\text { Descrip- } \\
\text { tion }\end{array}$ & $\begin{array}{c}\text { Distance } \\
\text { above } \\
\text { land- } \\
\text { surface } \\
\text { datum } \\
\text { (feet) }\end{array}$ & & & \\
\hline $\begin{array}{r}24.31 .4 .430 \\
17.111\end{array}$ & W. M. Snyder........ & $\begin{array}{l}3,420 \\
3,510\end{array}$ & $\begin{array}{r}626.5 \\
85.0\end{array}$ & $\begin{array}{l}5 \\
7\end{array}$ & $\begin{array}{r}423.6 \\
68.4\end{array}$ & $\begin{array}{l}3-13-59 \\
3-25-59\end{array}$ & $\begin{array}{l}\text { Tcb } \\
\text { Te }\end{array}$ & $\begin{array}{l}0.9 \\
1.2\end{array}$ & $\begin{array}{l}\text { Prc } \\
\text { Qg }\end{array}$ & $\begin{array}{l}\text { L, W, S } \\
\text { L, w, S, D }\end{array}$ & $\begin{array}{l}\text { "Ingle well." Well not cased. L, CAl } \\
\text { "Ranch Headquarters well." We.l } \\
\text { cased to total depth, R. L, CA. }\end{array}$ \\
\hline 33. 124 & _..._do_..... & 3,460 & 698.0 & 5 & 474.2 & $3-12-59$ & Tc & 1.0 & Prc & $\mathbf{L}, \mathbf{W}, \mathbf{s}$ & $\begin{array}{l}\text { "Keyhole well." Well cased to total } \\
\text { depth, R. L, CA. }\end{array}$ \\
\hline 24. 32. 3. 322 & Frank James.... & 3,650 & 550 & 10 & & & & $-\infty$ & $\mathbf{k r}$ & $\mathbf{L}, \mathbf{W}, \mathrm{S}$ & $\begin{array}{l}\text { "New well." Two wells at this lo- } \\
\text { cation. Surface casing only, R. }\end{array}$ \\
\hline 3. $322 \mathrm{a}$ & .....do. & 3,650 & 500 & 8 & (....... & 4-13-59 & -...- & ...... & Fr & $\mathbf{N}, \mathbf{N}, \mathbf{N}$ & $\begin{array}{l}\text { Well dry and caved in. Surface casing } \\
\text { only, } R \text {. }\end{array}$ \\
\hline 10.344 & . do & 3,588 & 60 & 6 & 33.6 & $4-13-59$ & Te & 1.0 & Qal & $\mathrm{L}, \mathrm{W}, \mathrm{S}, \mathrm{D}$ & $\begin{array}{l}\text { "Ranch Headquarters well." Surface } \\
\text { casing only, R. }\end{array}$ \\
\hline $\begin{array}{r}24.32 .33 .422 \\
25.29 . \\
2.111 \\
16.444\end{array}$ & Richard Ritz.... & $\begin{array}{l}3,510 \\
3,000 \\
3,025\end{array}$ & $\begin{array}{l}366.4 \\
140.0 \\
200(?)\end{array}$ & $\begin{array}{r}12 \\
8 \\
6\end{array}$ & $\begin{array}{l}313.4 \\
100.6 \\
170.1\end{array}$ & $\begin{array}{r}2-18-59 \\
10-23-58 \\
8-19-58\end{array}$ & $\begin{array}{l}\text { Tc } \\
\mathbf{L s} \\
\text { Te }\end{array}$ & $\begin{array}{r}.6 \\
.0 \\
1.2\end{array}$ & $\begin{array}{l}\text { E } \\
\text { Prc(?) } \\
\text { Prc }\end{array}$ & $\begin{array}{l}\mathrm{L}, \mathrm{W}, \mathrm{S} \\
\mathbf{N}, \mathbf{N}, \mathbf{N} \\
\mathrm{L}, \mathrm{W}\end{array}$ & $\begin{array}{l}\text { "Burro well." } \\
\text { Potash test hole. Drilled to } 857 \text { feet. } \\
\text { "Pickett well." Well cased to total } \\
\text { depth, R. CA. }\end{array}$ \\
\hline 32.211 & do & 2,985 & 110.6 & 8 & 98.7 & $3-24-59$ & Te & .9 & Prc & $\mathbf{N}, \mathbf{N}, \mathbf{N}$ & $\begin{array}{l}\text { Surface casing only. Potash test hole. } \\
\text { L, CA. }\end{array}$ \\
\hline 25.30 .7 .111 & W. M. Snyder & 3,170 & 385.6 & 7 & 263.3 & $3-7-59$ & Te & .0 & QTu & $\mathbf{L}, \mathbf{W}, \mathbf{s}$ & $\begin{array}{l}\text { "Carper well." Well cased to } 250 \text { feet. } \\
\text { Oil test hole converted to water } \\
\text { well. L, CA. }\end{array}$ \\
\hline $\begin{array}{l}\text { 7. } 330 \\
8.224 \\
8.224 a\end{array}$ & $\begin{array}{l}\text { Ralph Lowe. } \\
\text { W. M. Snyder......... }\end{array}$ & $\begin{array}{l}3,180 \\
3,220 \\
3,220\end{array}$ & $\begin{array}{r}295.0 \\
343.5\end{array}$ & $\begin{array}{l}7 \\
7\end{array}$ & 309.7 & $\begin{array}{l}6-14-51 \\
8-19-58\end{array}$ & Tc & 0 & $\begin{array}{l}\text { QTu } \\
\text { QTu } \\
\text { QTu }\end{array}$ & $\begin{array}{l}\mathbf{N}, \mathbf{N}, \mathbf{N} \\
\mathbf{N}, \mathbf{N}, \mathbf{N} \\
\mathbf{N}, \mathbf{N}, \mathbf{N}\end{array}$ & $\begin{array}{l}\text { Drilled to supply water for oil tests. } \\
\text { Three wells at this location. } \\
\text { Hole crooked, } \mathbf{R} \text {. }\end{array}$ \\
\hline $\begin{array}{l}8.224 \mathrm{~b} \\
12.113\end{array}$ & (ndo do & $\begin{array}{l}3,220 \\
3,375\end{array}$ & 460.3 & $\begin{array}{l}7 \\
5\end{array}$ & $\begin{array}{l}\text { P332. } 55 \\
\text { 391.3 }\end{array}$ & $\begin{array}{l}6-14-61 \\
3-25-59\end{array}$ & $\begin{array}{l}\text { Te } \\
\text { Tc }\end{array}$ & $\begin{array}{r}1.0 \\
.7\end{array}$ & $\begin{array}{l}\text { QTu } \\
\text { OTu }\end{array}$ & $\begin{array}{l}\mathbf{L}, \mathbf{W}, \mathbf{S} \\
\mathbf{N}, \mathrm{N}, \mathrm{N}\end{array}$ & $\begin{array}{l}\text { "Tomeat well." } \\
\text { Drilled to supply water for oil test. L. }\end{array}$ \\
\hline $\begin{array}{r}21.333 \\
25.31 .21 .400\end{array}$ & $\begin{array}{l}\text { Mrs. E. R. Johnson } \\
\text { and others. }\end{array}$ & $\begin{array}{l}3,200 \\
3,340\end{array}$ & $\begin{array}{l}298.1 \\
400\end{array}$ & $\begin{array}{l}6 \\
7\end{array}$ & $\begin{array}{l}\text { P266.1 } \\
\text { P318. } 0\end{array}$ & $\begin{array}{l}2-5-59 \\
2-17-59\end{array}$ & $\begin{array}{l}\text { Te } \\
\text { Te }\end{array}$ & $\begin{array}{r}1.0 \\
.4\end{array}$ & $\begin{array}{l}\text { QTu } \\
\text { QTu }\end{array}$ & $\begin{array}{l}\text { L, W, S, D } \\
\text { L, W, s, D }\end{array}$ & $\begin{array}{l}\text { Well cased to total depth, R. CA. } \\
\text { Do. }\end{array}$ \\
\hline 25.33 .20 .443 & - & 3,395 & $\begin{array}{l}200- \\
250\end{array}$ & 6 & & & & $\cdots$ & $\mathbf{F}$ & $\mathrm{L}, \mathrm{w}, \mathrm{s}$ & \\
\hline $\begin{array}{l}26.29 .22 .340 \\
26.30 .5 .334\end{array}$ & $\begin{array}{l}\text { J. G. Ross } \\
\text { El Paso Natural Gas } \\
\text { Co. }\end{array}$ & $\begin{array}{l}2,875 \\
3,090\end{array}$ & $\begin{array}{l}200(?) \\
770\end{array}$ & $\begin{array}{r}6 \\
11\end{array}$ & $\begin{array}{r}68.7 \\
169.9\end{array}$ & $\begin{array}{l}8-19-58 \\
2-18-59\end{array}$ & $\begin{array}{l}\text { Te } \\
\text { Epb }\end{array}$ & $\begin{array}{l}2.0 \\
1.9\end{array}$ & $\begin{array}{l}\text { Prc } \\
\text { QTu }\end{array}$ & $\begin{array}{l}\mathrm{L}, \mathrm{W}, \mathrm{S} \\
\mathbf{T}, \mathrm{Ic}, \mathrm{In}, \mathrm{D}\end{array}$ & $\begin{array}{l}\text { Well not used recently. } \\
\text { Water well No. } 1 \text { Pecos Turbine sta- } \\
\text { tion. Cased to total depth. }\end{array}$ \\
\hline 5.343 & - do & 3,100 & 775 & 11,9 & 182.6 & $8-18-58$ & Tap & 3.3 & QTu & $\mathrm{T}, \mathrm{Ic}, \mathrm{In}, \mathrm{D}$ & $\begin{array}{l}\text { Water well No. } 2 \text { Pecos Turbine } \\
\text { station. Cased to total depth. CA. }\end{array}$ \\
\hline 8.111 & $\begin{array}{l}\text { Mrs. E. R. Johnson } \\
\text { and others. }\end{array}$ & 3,085 & 400 & 7 & 163.8 & $2-18-59$ & Tem & .3 & QTu & $\mathrm{L}, \mathrm{W}, \mathrm{S}$ & “West well.” \\
\hline 26.31. 8.310 & Ross Estate......... & 3,230 & 309.6 & 6 & P287. 1 & $2-18-59$ & Tc & 1.4 & QTu & L, W, S, D & $\begin{array}{l}\text { "Ranch Headquarters well." Two } \\
\text { wells at this location. }\end{array}$ \\
\hline $8.310 \mathrm{a}$ & .... do do & 3,230 & 324.5 & 6 & 275.8 & $8-18-58$ & Tc & 1.5 & QTu & $\mathbf{N}, \mathbf{N}, \mathbf{N}$ & Well has never been placed in ser vice \\
\hline
\end{tabular}

cal characteristics and radioactivity background level of the water in the study area before the nuclear explosion. Results of chemical and radiochemical analyses are given in tables 3 and 4.

Because of the lapse of time between the nuclear event and the original investigation of the nine privately owned wells within a 5-mile radius of the test site, a second investigation of the wells (and of an additional well drilled in May 1961) to establish their depth and water level and to determine the condition of pumps was made November 23 to December 9,1961 . For both investigations the pumps were removed by a contractor of the U.S. Atomic Energy Commission, and measurements were made by personnel of the U.S. Geological Survey.

The owner, depth of well, depth to water, and condition of the pump for each well within the 5-mile radius are listed in table 5. Depth and water-level data obtained from both investigations are included.

\section{OBSERVATIONS AT TIME OF NUGLEAR EXPLOSION}

At the time of the nuclear explosion, ground-water levels close to the site were under observation at U.S.
Geological Survey test holes 1, 2, 4, and 5. Observations were also made in two wells near the Malaga Bend of the Pecos River south of Carlsbad, N. Mex., 9 miles west of the project site, and in others wells to the north in the Roswell artesian basin.

The four observation wells at and near the project site had float-type continuous recording gages. The rocording gages consist essentially of a height-element mechanism to register the level of the water surface and a clock movement which feeds a chart at a constant rate while a marking stylus moves laterally across the chart and produces a graphic record of water level against time. Water-level changes are transmitted to the heightelement mechanism and stylus by a wire line attached to a counterweighted float which rests on the water surface. The gages were equipped with a time-element mechanism which moved the chart at a rate of 0.1 inch per hour. The height element registered a graph change of 2 inches for each foot of water-level change in holes 1 and 4, and 10 inches for each foot of water-level change in holes 2 and 5 .

The recording gages were housed in metal shelters over the well casing. The shelters were securely bolted to a concrete platform, and the gages were fastened to the shelters. For several days before the explosion, the 


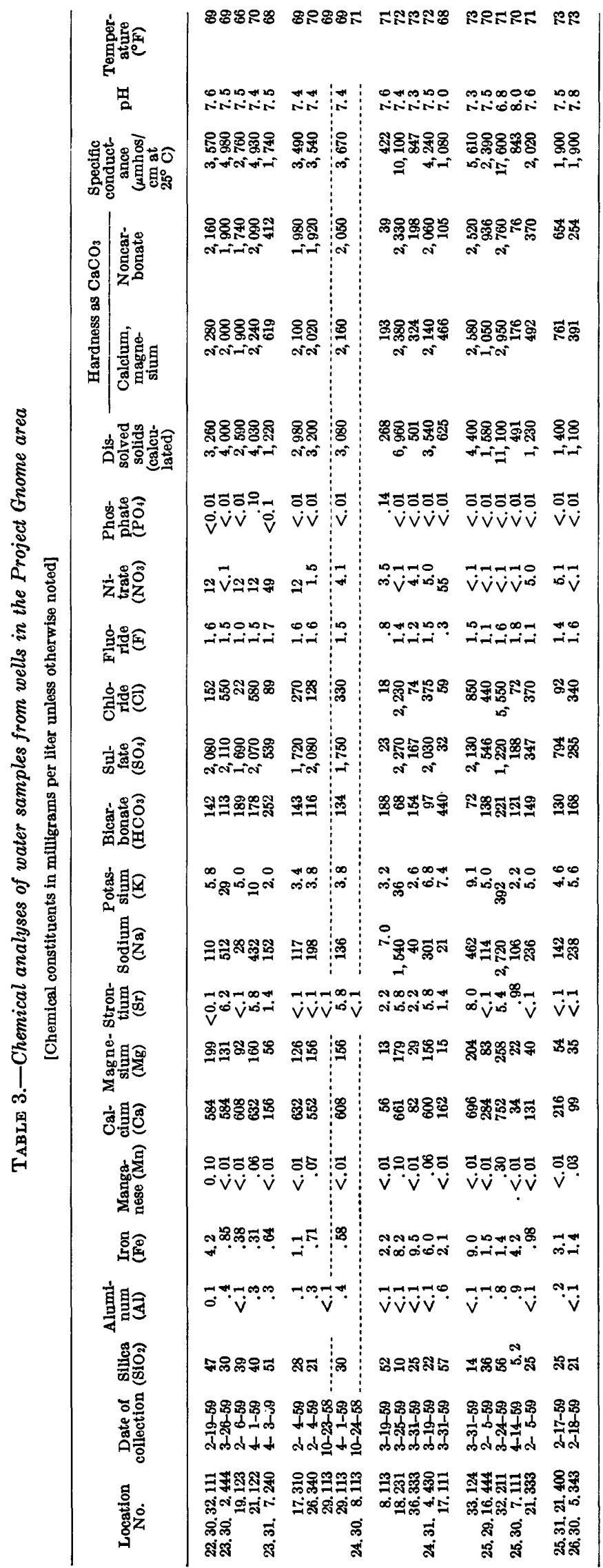


TABLE 4.-Radiochemical analyses of well water in the Project Gnome area

\begin{tabular}{|c|c|c|c|c|c|c|c|c|c|}
\hline \multirow{2}{*}{ Location No. } & \multirow{2}{*}{$\begin{array}{c}\text { Date } \\
\text { of } \\
\text { collection }\end{array}$} & \multicolumn{2}{|c|}{$\begin{array}{l}\text { Alpha activity as } \\
\text { U equivalent }\end{array}$} & \multicolumn{2}{|c|}{$\begin{array}{l}\text { Beta } \\
\text { activity as } \\
\text { Sryo- }\end{array}$} & \multirow{2}{*}{$\underset{(\mu \mathrm{g} / 1)}{\text { Uranium }}$} & \multirow{2}{*}{$\begin{array}{l}\text { Radium } \\
\text { as Ra228 } \\
\text { (pc } / I)\end{array}$} & \multirow{2}{*}{$\begin{array}{c}\text { Net } \\
\text { extractable } \\
\text { alpha, } \\
\text { U equivalent } \\
\text { (pc/) }\end{array}$} & \multirow{2}{*}{$\begin{array}{l}\text { Strontium- } / 1) \\
\text { Seg }\end{array}$} \\
\hline & & $(\mathrm{pc} / \mathrm{l})$ & $\begin{array}{c}\text { Date } \\
\text { determined }\end{array}$ & $(\mathrm{pe} / \mathrm{l})$ & $\begin{array}{c}\text { Date } \\
\text { determined }\end{array}$ & & & & \\
\hline $\begin{array}{r}22.30 .32 .111 \\
23.30 .2 .444 \\
19.123 \\
21.122 \\
23.31 . \quad 7.240\end{array}$ & $\begin{array}{l}2-19-59 \\
3-26-59 \\
2-6-59 \\
4-1-59 \\
4-3-59\end{array}$ & $\begin{array}{r}21 \\
71 \\
<21 \\
<35 \\
11\end{array}$ & $\begin{array}{l}6-8-59 \\
6-8-59 \\
6-5-59 \\
6-9-59 \\
6-9-59\end{array}$ & $\begin{array}{r}72 \\
200 \\
72 \\
120 \\
12\end{array}$ & $\begin{array}{l}7-7-59 \\
7-6-59 \\
7-6-59 \\
7-7-59 \\
6-23-59\end{array}$ & $\begin{array}{c}18 \\
38 \\
9.5 \\
16 \\
6.3\end{array}$ & $\begin{array}{r}0.3 \\
13 \\
.6 \\
.5 \\
.2\end{array}$ & $\begin{array}{l}<4.0 \\
17 \\
<2 \\
10 \\
4.3\end{array}$ & \\
\hline $\begin{array}{r}17.310 \\
26.340 \\
29.113 \\
29.113 \\
24.30 . \quad 8.113\end{array}$ & $\begin{array}{r}2-4-59 \\
2-4-59 \\
10-23-58 \\
4-1-59 \\
10-24-58\end{array}$ & $\begin{array}{r}62 \\
100 \\
23 \\
<25 \\
3.0\end{array}$ & $\begin{array}{l}6-8-59 \\
5-26-59 \\
3-10-59 \\
6-9-59 \\
3-9-59\end{array}$ & $\begin{array}{r}100 \\
210 \\
25 \\
27 \\
3.1\end{array}$ & $\begin{array}{l}7-7-59 \\
7-7-59 \\
4-22-59 \\
6-23-59 \\
4-22-59\end{array}$ & $\begin{array}{l}8.6 \\
16 \\
9.0 \\
9.9 \\
2.8\end{array}$ & $\begin{array}{r}.1 \\
<.8 \\
.1 \\
.1 \\
.1\end{array}$ & $\begin{aligned} & 3 \\
&<3 \\
& 2.5 \\
&<2 \\
&<.8\end{aligned}$ & \\
\hline $\begin{array}{r}8.113 \\
18.231 \\
36.333 \\
24.31 . \quad 4.430 \\
17.111\end{array}$ & $\begin{array}{l}3-19-59 \\
3-25-59 \\
3-31-59 \\
3-19-59 \\
3-31-59\end{array}$ & $\begin{array}{c}6.0 \\
<36 \\
3.9 \\
67 \\
<7.4\end{array}$ & $\begin{array}{l}6-8-59 \\
5-26-59 \\
6-9-59 \\
6-8-59 \\
6-9-59\end{array}$ & $\begin{array}{r}18 \\
320 \\
30 \\
250 \\
36\end{array}$ & $\begin{array}{l}7-6-59 \\
7-6-59 \\
7-6-59 \\
7-6-59 \\
7-16-59\end{array}$ & $\begin{array}{l}\text { 1. } 7 \\
\text { 2. } 8 \\
\text { 5. } 2 \\
9.2 \\
\text { 4. } 1\end{array}$ & $\begin{array}{r}.2 \\
.9 \\
.2 \\
4.7 \\
1.8\end{array}$ & $\begin{array}{r}45 \\
4.2 \\
3.8 \\
<2 \\
1.2\end{array}$ & \\
\hline $\begin{array}{l}\text { 25. } 31.21 .400 \\
\text { 26. } 30 . \quad 5.343\end{array}$ & $\begin{array}{l}2-12-59 \\
2-18-59\end{array}$ & $\begin{array}{r}<12 \\
28\end{array}$ & $\begin{array}{l}6-8-59 \\
6-8-59\end{array}$ & $\begin{array}{l}48 \\
68\end{array}$ & $\begin{array}{l}7-6-59 \\
7-7-59\end{array}$ & $\begin{array}{l}9.6 \\
1.1\end{array}$ & $\begin{array}{l}.2 \\
.4\end{array}$ & $<^{4} .2$ & \\
\hline
\end{tabular}

gages were visited periodically and adjusted for time and gage height. The final check was made 11 hours before the detonation.

On December 11, about 24 hours after the explosion, records were collected at the four observation wells. The following effects were noted.

The concrete platform, 6 inches thick and 6 feet square, around the well casing at test hole 1 contained cracks, as much as $1 / 8$ inch wide, radiating outward from opposite sides of the well casing. Although no cracks

TABLE 5.-Water wells within a 5-mile radius of Project Gnome site, Eddy County

\begin{tabular}{|c|c|c|c|c|c|}
\hline Location No. & Owner & $\begin{array}{c}\text { Depth } \\
\text { of } \\
\text { well }\end{array}$ & $\begin{array}{l}\text { Depth } \\
\text { to } \\
\text { water }\end{array}$ & $\begin{array}{c}\text { Date } \\
\text { measured }\end{array}$ & $\begin{array}{l}\text { Condition } \\
\text { of pump }\end{array}$ \\
\hline $\begin{array}{r}23.30 .2 .444 \mathrm{a} \\
19.123 \\
21.122 \\
23.31 .17 .310 \\
29.113 \\
24.30 .8 .113 \\
12.430 \\
18.231 \\
23.312 \\
24.31 .17 .111\end{array}$ & $\begin{array}{l}\text { C. H. and } \\
\text { W. O. James. } \\
\text { James and } \\
\text { Briones. } \\
\text { C. H. and } \\
\text { W. O. James. } \\
\\
\text { Bill Eaton } \\
\text { W. M. Snyder.... } \\
\text { Bill Eaton } \\
\text { W. M. Snyder } \\
\end{array}$ & $\begin{array}{r}318.4 \\
316.4 \\
89.0 \\
88.2 \\
203.6 \\
204.5 \\
354.0 \\
350.3 \\
223.9 \\
222.8 \\
191.9 \\
198.4 \\
495.6 \\
451.6 \\
449.8 \\
428.1 \\
456.4 \\
85.0 \\
80.1\end{array}$ & $\begin{array}{r}260.5 \\
259.0 \\
70.4 \\
71.3 \\
179.2 \\
177.1 \\
109.4 \\
108.2 \\
138.4 \\
140.2 \\
176.0 \\
176.3 \\
364.6 \\
227.8 \\
231.9 \\
423.1 \\
426.2 \\
68.4 \\
66.2 \\
\end{array}$ & $\begin{array}{r}4-20-59 \\
11-25-61 \\
4-7-59 \\
11-23-61 \\
4-6-59 \\
11-26-61 \\
3-27-59 \\
11-27-61 \\
3-26-59 \\
11-29-61 \\
3-23-59 \\
12-8-61 \\
12-7-61 \\
3-19-59 \\
12-9-61 \\
3-26-59 \\
12-7-61 \\
3-25-69 \\
12-7-61\end{array}$ & $\begin{array}{l}\text { Good. } \\
\text { Do. } \\
\text { Fair. } \\
\text { Fair to bad. } \\
\text { Fair. } \\
\text { Fair to bad. } \\
\text { Good. } \\
\text { Do. } \\
\text { Do. } \\
\text { Do. } \\
\text { Do. } \\
\text { Do. } \\
\text { Do. } \\
\text { Fair } \\
\text { Do. } \\
\text { Good. } \\
\text { Do. } \\
\text { Do. } \\
\text { Fair to good. }\end{array}$ \\
\hline
\end{tabular}

were observed in the ground adjacent to the platform, beginning about 25 feet south of the well a circular crack 30 to 40 feet in diameter and ranging in width from a hairline to one-fourth of an inch was observed. This crack appears to have formed over the perimeter of the filled-in mud pit used when the well was drilled.

The metal shelter and gage housing at test hole 1 were undamaged. However, the recording gage had been badly shaken, and the record ended shortly after the explosion. The stylus recorded a partial trace of water-level rise, from which the maximum fluctuation was estimated.

There was no apparent damage to the concrete platform, metal shelter, or gage housing at test holes 2 and 5. Both recording gages had been shaken and had not operated properly after the explosion. Incomplete traces of water-level changes immediately following the explosion were apparent on both charts.

The only disturbance at test hole 4 was minor misalinement of the recording gage. The recorder continued to operate and traced water-level fluctuations that immediately followed the explosion.

Figure 10 is a hydrograph of test hole 4 showing the fluctuations of water level at the time of the nuclear explosion. The water level responded instantaneously to pressures exerted in the aquifer. The water level rose 2.2 feet, and the peak of the rise was followed immediately by a sharp decline of water level. The decline grad- 
ually slowed, and the water level in the well returned to normal after about 11 hours.

A summary of water-level changes in the four observation wells, at and immediately after the explosion, as indicated by recording gages, follows : Test hole $1(2,000$ $\mathrm{ft}$ from ground zero), estimated rise of 3.97 feet; test hole 2 (about 2 miles from ground zero), rise of at least 0.50 foot; test hole 4 (about $3,200 \mathrm{ft}$ from ground zero), rise of 2.2 feet; and test hole 5 (about $4,000 \mathrm{ft}$ from ground zero), rise of at least 0.40 foot.

Water levels in all observation wells were measured with a steel tape on December 12, 1961, 2 days following the nuclear explosion. The water levels in the wells were essentially the same as those measured before the explosion. Only insignificant changes in altitude of the measuring points at these wells resulted from the explosion. Wells 1,4 , and 5 were resurveyed in January 1962. Test hole 1 was 0.09 foot lower than before the explosion, and test hole 4 was 0.04 foot lower. No change was found at test hole 5.

\section{INVESTIGATIONS AFTER THE NUCLEAR EXPLOSION}

\section{WATER-LEVEL FLUCTUATIONS}

Water levels were observed in Geological Survey test hole 1 from September 1960 to June 1963. During most of this period a continuous water-stage recording gage was operated in the test hole. The range of fluctuations of water level from the initial observations in September 1960 to the detonation of December 10, 1961, was about 1 foot.

Figure 11 is a hydrograph showing the fluctuations of water level observed in test hole 1 during the period of record. The depth-to-water measurements shown on the hydrograph are daily high measurements recorded on the first day of each month. No measurement is shown for February 1961, as grouting in the access shaft caused abnormal lowering and fluctuations of water level in the aquifer (fig. 9).

During the period of record the general pattern was one of slowly rising water levels. The maximum variation in depth to water was about $21 / 2$ feet.

The general pattern of water-level fluctuation in test hole 2, also under observation from October 1960 to June 1963, was similar to that observed in test hole 1. However, the fluctuations of water level in test hole 2 were not as large as those in test hole 1.

\section{EFFECTS OF ATMOSPHERIC PRESSURE AND EARTH TIDES}

Water levels in wells tapping artesian aquifers respond to changes in atmospheric pressure. An increase in atmospheric pressure causes the water level to decline, and a decrease in atmospheric pressure causes the water level to rise. Water-level fluctuations produced by earth tides, which are caused by the forces exerted on the earth's crust by the sun and the moon, have also been observed in artesian wells.

The effects of both atmospheric pressure and earth tides on water levels in the Culebra Dolomite Member at the project site are recognized on the charts of the water- level recording gage in test hole 1 . Figure 12 is a reproduction of this recorder chart for January 9-14, 1963. The atmospheric pressure, expressed in feet of water, was recorded on barographs at test holes 4 and 8. The effects of atmospheric pressure and earth tides on water levels, shown in figure 12, are insignificant in relation to the effects on water levels that would be caused by leakage of water from the aquifer into the Gnome cavity.

The traces of the water level and of the barometric pressure are in general similar in their major fluctuations; however, in detail, they are dissimilar. The water levels in the aquifer show a fairly regular semidiurnal fluctuation of a few tenths of a foot, with high-water

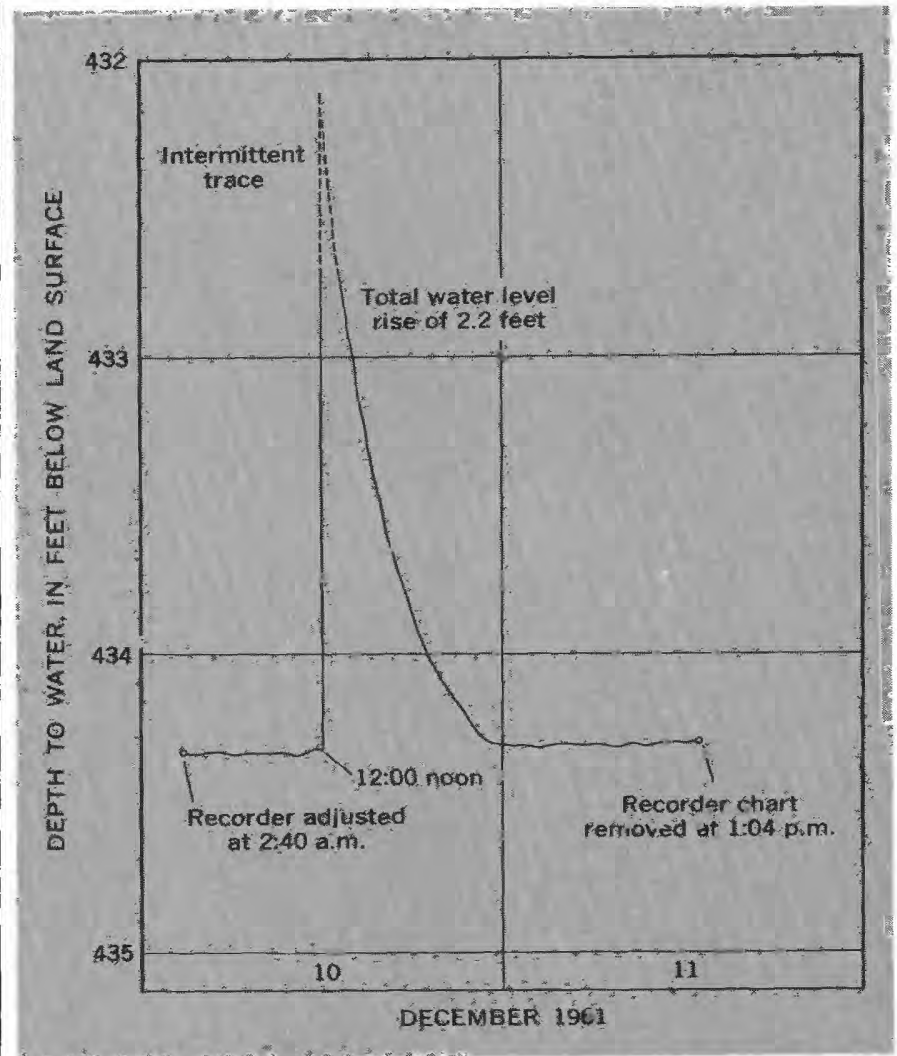

FIgURE 10.-Fluctuation of water level in U.S. Geological Survey test hole 4 at time of Project Gnome explosion, Project Gnome site. 


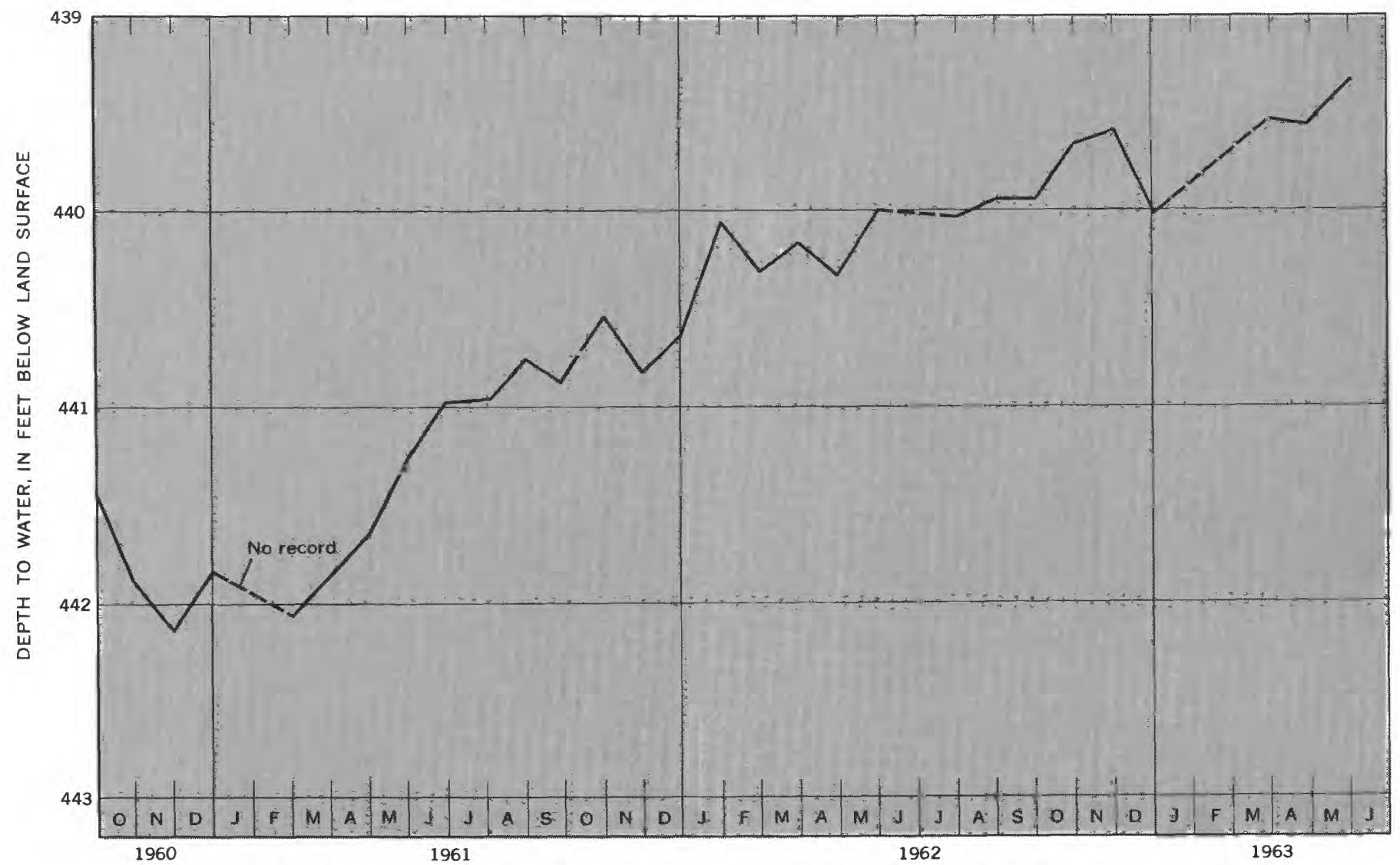

FIgURE 11.-Water level in U.S. Geological Survey test hole 1, 1960-63, Project Gnome site.

levels near midnight and noon, and low-water levels near 0600 and 1800 . These semidiurnal fluctuations are similar to fluctuations caused by earth tides, observed by Robinson (1939, p. 656) in a well about 9 miles northwest of the Project Gnome site. During periods of strong atmospheric pressure changes, such as January 11-13, 1963, the effects of earth tides are largely masked, and the principal cause of water-level fluctuations is barometric.

The separate effects of atmospheric pressure and of earth tides upon water levels in the aquifer at the Project Gnome site have not been thoroughly investigated. These cyclic phenomena, however, are recognized and are given consideration in the interpretation of changes of water level in the aquifer.

\section{CONCLUSIONS}

Initial geologic and hydrologic investigations, including an examination of all wells within 15 miles of the Project Gnome site, showed that water is obtained

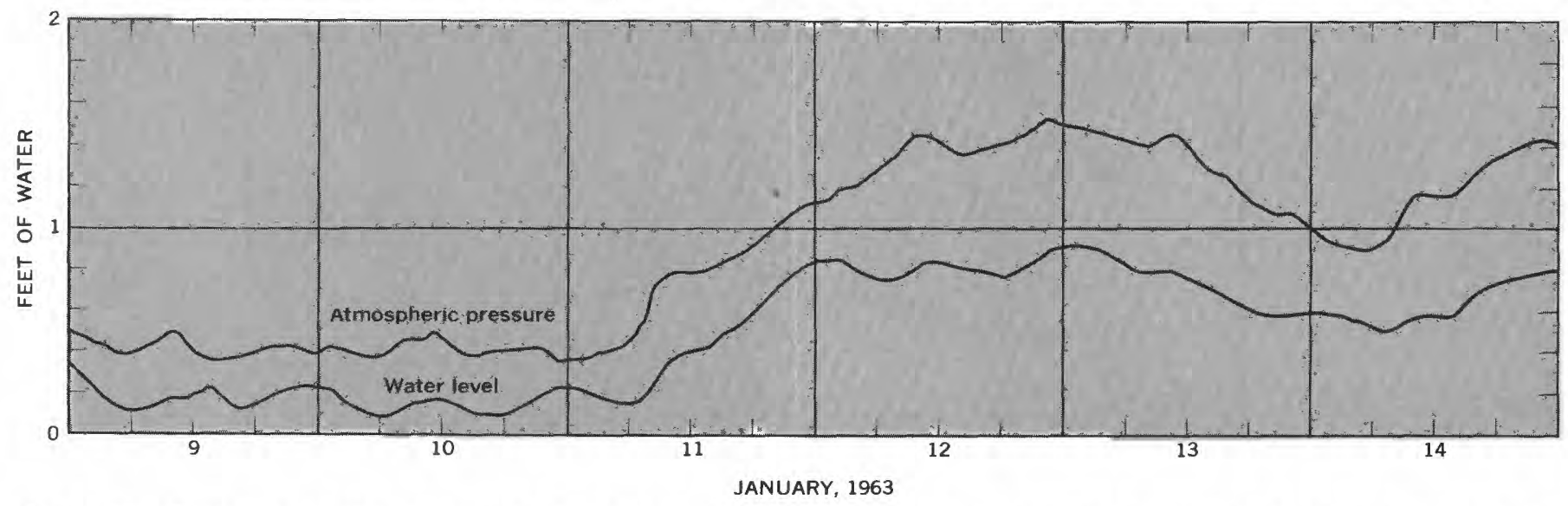

Figure 12.-Fluctuations of water level in U.S. Geological Survey test hole 1 and inverted fluctuations of atmospheric pressure, January 9-14, 1963, Project Gnome site. 
from wells tapping rocks of various ages. Most of the ground water in the area is saline; however, because it is the principal source of stock water, and is widely utilized as such, it is a valuable resource. A brine aquifer (residual layer of the Rustler Formation) west of the site and in Nash Draw, from which no water is utilized for beneficial purposes, causes a deterioriation in the chemical quality of the Pecos River waters downstream from the site. The aquifers lie above the top of the massive salt of the Salado Formation (the formation in which the Project Gnome nuclear device was detonated). No water is known to exist within the salt, and no fresh water is known to be in the underlying rocks.

The Culebra Dolomite Member of the Rustler Formation is the only aquifer at the Project Gnome site. This aquifer lies nearly 200 feet above the top of the massive salt and about 500 feet beneath the land surface. Water in the aquifer moves past the project site, at an estimated rate of one-half foot per day, in a generally southwestward to westward direction from recharge areas to the northeast, and ultimately discharges into the Pecos River.

Observations of water level in the aquifer at the Project Gnome site, made for several months before the nuclear explosion, showed that natural fluctuations of water level were small. However, pressure changes in the aquifer, due to the release of water through drill holes and removal by bailing, were readily detected by a recording gage installed in an observation test hole at the site.

Water-level observations made at the time of and within a few days following the detonation showed no evidence of water leaking into or out of the aquifer at the Project Gnome site, suggesting that the Culebra Dolomite Member probably was not significantly ruptured by the explosion. Moreover, there was no apparent abnormal change of water level in the aquifer beneath the member and above the top of the salt of the Salado Formation in test holes 2 and 5 .

Water-level records were examined for other wells in the Carlsbad area and to the north in the Roswell artesian basin. In many of these wells the water level normally fluctuates a few tenths of a foot in response to natural earthquakes. In the two wells near Malaga Bend, 9 miles west of the Project Gnome site, fluctuations of 0.06 foot persisted for a few seconds after the nuclear explosion, but no fluctuation of water level was detected in any other well under observation in the Roswell basin.

Observations of water level at the Project Gnome site were continued after the nuclear explosion, and the network of points where the potentiometric surface can be observed was expanded by the use of three drill holes as observation wells. Since the time of the nuclear explosion no anomalous water-level fluctuation has been observed in the continuous record of water levels measured in test hole 1.

Water levels in the Culebra Dolomite Member at the Project Gnome site are affected by changes in atmospheric pressure and by effects attributed to earth tides, although these effects have not been intensively studied for this report.

Data obtained from a pumping test on test hole 1 and from concurrent measurements in test holes 6 and 8 were used to estimate the potential yield of wells at the Project Gnome site. It was estimated that $100 \mathrm{gpm}$ could be pumped from a well continuously for a period of 1 year without lowering the water level below the top of the aquifer. Larger quantities of water could be pumped for shorter periods of time, and smaller quantities could be obtained for much longer periods before the water level would be lowered to the top of the aquifer.

\section{SELECTED REFERENCES}

Adams, J. E.. 1944, Upper Permian Ochoa series of Delaware basin, West Texas and southeastern New Mexico: Am. Assoc. Petroleum Geologists Bull., v. 28, no. 11, p. 1596-1625, 4 figs.

Adams, J. E., and Frenzel, H. N., 1950, Capitan barrier reef, Texas and New Mexico: Jour. Geology, v. 58, no. 4, p. 289-312.

Adams, J. E., and others, 1939, Standard Permian section of North America: Am. Assoc. Petroleum Geologists Bull., v. 23, no. 11, p. 1673-1681.

Baltz, E. H., 1959, Diagram showing relations of Permian rocks in part of Eddy County, New Mexico: U.S. Geol. Survey TEM-1035, open-file report.

Bjorklund, L. J.. and Motts, W. S., 1959, Geology and water resources of the Carlsbad area, Eddy County, New Mexico: U.S. Geol. Survey open-file report, 322 p., 15 pls., 56 figs.

Blanchard, W. G., Jr., and Davis, M. J., 1929, Permian stratigraphy and structure of parts of southeastern New Mexico and southwestern Texas: Am. Assoc. Petroleum Geologists Bull., v. 13, no. 8, p. 957-995. 2 pls., 10 figs.

Cooper, J. B., 1960; Geologic section from Carlsbad Caverns National Park through the Project Gnome site, Eddy and Lea Counties, New Mexico: U.S. Geol. Survey TEI-767, open-file report.

- 1961, Test holes drilled in support of ground-water investigations, Project Gnome, Eddy County, New Mexicobasic data report: U.S. Geol. Survey TEI-786, open-file report. 116 p., 12 figs.

1962, Ground-water investigations of the Project Gnome area, Eddy and Lea Counties, New Mexico: U.S. Geol. Survey TEI-802, open-file report, 67 p., 17 figs.

Cooper. J. B., and others, 1962, Hydrologic and geologic studies for Project Gnome, preliminary report: U.S. Geol. Survey Project Gnome Report PNE-130P, 54 p. [Available from Clearinghouse for Federal Scientific and Technical Information, U.S. Dept. Commerce, Springfield, Va. 22151] 
Crandall, K. H., 1929, Permian stratigraphy of southeastern New Mexico and adjacent parts of western Texas: Am. Assoc. Petroleum Geologists Bull., v. 13, no. 8, p. 927-914, 1 pl., 6 figs.

Dane, C. H., and Backman, G. O., 1958, Preliminary geologic map of the southeastern part of New Mexico: U.S. Geol. Survey Misc. Geol. Inv. Map I-256.

Darton, N. H., 1928, "Red Beds" and associated formations in New Mexico. with an outline of the geology of the State: U.S. Geol. Survey Bull. 794, 356 p., 62 pls [1929]

DeFord, R. K., and Lloyd, E. R., 1940, Editorial introduction, in West Texas-New Mexico symposium, pt. 1: Am. Assoc. Petroleum Geologists Bull., v. 24, no. 1, p. 1-14, 3 figs.

Dickey, R. I.. 1940, Geologic section from Fisher County through Andrews County, Texas, to Eddy County, New Mexico, in DeFord, R. K., and Lloyd, E. R., [eds.], West Texas-New Mexico symposium, pt. 1: Am. Assoc. Petroleum Geologists Bull., v. 24, no. 1, p. 37-51, 1 fig.

Fenneman, N. M., 1931, Physiography of western United States: New York. McGraw-Hill Book Co., 534 p.

Ferris, J. G., Knowles, D. B., Brown, R. H., and Stallman, R. W., 1962, Theory of aquifer tests: U.S. Geol. Survey WaterSupply Paper 1536-E, 174 p., 29 figs.

Flawn, P. T., 1954, Texas basement rocks-a progress report: Am. Assoc. Petroleum Geologists Bull., v. 38, no. 5, p. 900-912, 2 figs.

Gard, L. M., Jr., 1968, Geologic studies, Project Gnome, Eddy County, New Mexico: U.S. Geol. Survey Prof. Paper 589, 33 p., 15 figs.

Gard, L. M., Cooper, J. B., and others, 1962, Hydrologic and geologic studies for Project Gnome: U.S. Geol. Survey Project Gnome Report PNE-130F, 196 p. [Available from Clearinghouse for Federal Scientific and Technical Information, U.S. Dept. Commerce, Springfield, Va. 22151]

Hale, W. E., Hughes, L. S., and Cox, E. R., 1951, Possible improvement of quality of water of the Pecos River by diversion of brine at Malaga Bend, Eddy County, New Mexico: Pecos River Commission, New Mexico and Texas, in cooperation with U.S. Geol. Survey, Water Resources Div., Carlsbad, N. Mex., 43 p., 8 pls., 5 figs.

Hale, W. E., and Clebsch, Alfred, Jr., 1958, Preliminary appraisal of ground-water conditions in southeastern Eddy County and southwestern Lea County, New Mexico: U.S. Geol. Survey TEM-1045, open-file report, 23 p., 3 figs.

Hayes, P. T., 1958, Salt in the Ochoa series, New Mexico and Texas: U.S. Geol. Survey TEI-709, open-file report, 28 p., 4 figs.

Hem, J. D., 1970, Study and interpretation of the chemical characteristics of natural water $[2 \mathrm{~d}$ ed. $]$ : U.S. Geol. Survey Water-Supply Paper 1473, 363 p., 2 pls., 51 figs.

Hendrickson, G. E., and Jones, R. S., 1952, Geology and groundwater resources of Eddy County, New Mexico: New Mexico Bur. Mines and Mineral Resources, Ground-water Rept. 3, 169 p., 6 pls., 11 figs.

Hughes, P. W., 1954, New Mexico's deepest oil test, in New Mexico Geologic Soc. Guidebook 5th Field Conf., southeastern New Mexico: p. 124-130.

Jones, C. L., 1954, The occurrence and distribution of potassium minerals in southeastern New Mexico, in New Mexico Geol. Soc. Guidebook 5th Field Conf., southeastern New Mexico: p. 107-112.
1959, Thickness, character, and structure of Upper Permian evaporites in part of Eddy County, New Mexico: U.S. Geol. Survey TEM-1033, open-file report, 19 p. 2 figs.

King, P. B., 1942, Permian of west Texas and southeastern New Mexico, pt. 2 of DeFord and Lloyd [eds.], West Texas-New Mexico symposium: Am. Assoc. Petroleum Geologists Bull., v. 26 , no. 4 , p. 535-763, 2 pls., 2 figs.

-1948, Geology of the southern Guadalupe Mountains, Texas: U.S. Geol. Survey Prof. Paper 215, 183 p., 23 pls., 24 figs.

Kroenlein, G. A., 1939, Salt, potash, and anhydrite in Castile Formation of southeast New Mexico: Am. Assoc. Petroleum Geologists Bull., v. 23, no. 11, p. 1682-1693, 3 figs.

Kulp, J. L., 1961, Geologic time scale : Science, v. 133, no. 3459, p. 1111.

Lang, S. M., 1961, Methods for determining the proper spacing of wells in artesian aquifers: U.S. Geol. Survey WaterSupply Paper 1545-B, 16 p., 2 figs.

Lang, W. B., 1935, Upper Permian formations of Delaware basin of Texas and New Mexico: Am. Assoc. Petroleum Geologists Bull., v. 19, no. 2, p. 262-270, 7 figs.

1937, The Permian formation of the Pecos Valley of New Mexico and Texas: Am. Assoc. Petroleum Geologists Bull., v. 21, no. 7, p. 833-898, 29 figs.

1939. Salado Formation of the Permian basin: Am. Assoc. Petroleum Geologists Bull., v. 23, no. 10, p. 1569-1572.

Lloyd. E. R., 1929, Capitan Limestone and associated formations of New Mexico and Texas: Am. Assoc. Petroleum Geologists Bull., v. 13, no. 6, p. 645-658, 1 fig., 2 tables.

Maley, V. C., and Huffington, R. M., 1953, Cenozoic fill and evaporite solution in the Delaware Basin, Texas and New Mexico: Geol. Soc. America Bull., v. 64, no. 5, p. 539-545, 3 pls., 2 figs.

Meinzer, O. E., 1923a, The occurrence of ground water in the United States with a discussion of principles: U.S. Geol. Survey Water-Supply Paper 489, 321 p., 31 pls., 110 figs. 1923b, Outline of ground-water hydrology, with definitions: U.S. Geol. Survey Water-Supply Paper 494, 71 p., 35 figs.

Moore, G. W., 1958, Description of core from A.E.C. drill hole no. 1, Project Gnome, Eddy County, New Mexico: U.S. Geol. Survey TEM-927, open-file report, $27 \mathrm{p}$.

Needham, C. E., and Bates, R. L., 1943, Permian type sections in central New Mexico: Geol. Soc. America Bull., v. 54, no. 11. p. 1653-1667, 2 figs.

Newell, N. D., and others, 1953, 'The Permian reef complex of the Guadalupe Mountains region, Texas and New Mexicoa study in paleoecology: San Francisco, W. H. Freeman and Co., 236 p.

New Mexico Department of Public Health, 1955, Fluoridation in New Mexico-its present status: New Mexico State Dental Jour., v. 5, no. 4, February 1955.

New Mexico Geological Society, 1954, Guidebook of southeastern New Mexico, 5th Field Conf., Southeastern New Mexico, 1954 : 209 p.

Nicholson, Alexander, Jr., and Clebsch, Alfred, Jr., 1961, Geology and ground-water conditions in southern Lea County, New Mexico: New Mexico Bur. Mines and Mineral Resources Ground-Water Rept. 6, 123 p., 2 pls., 30 figs.

Robinson, T. W., 1939, Earth tides shown by fluctuations of water levels in wells in New Mexico and Iowa: Am. Geophys. Union Trans., pt. 4, p. 656-666. 
A24

HYDROLOGY OF NUCLEAR TEST SITES

Robinson, T. W., and Lang. W. B., 1938, Geology and groundwater conditions of the Pecos River valley in the vicinity of Laguna Grands de la Sal, New Mexico, with special reference to the salt content of the river water: New Mexico State Engineer 12th-13th Bienne. Reps., 1934-38, p. 77100, 5 pis., 3 figs.

Skinner, J. W., 1946, Correlation of Permian of west Texas and southeast New Mexico: Am. Assoc. Petroleum Geologists Bull., v. 30. no. 11, p. 1857-1874.

Stipp, T. F., and Hailer, T. B., 1956. Preliminary structure contour map of southeastern New Mexico showing oil and gas development: U.S. Geol. Survey Oil and Gas Inv. Map OM177 [1957].

Theis, C. V., 1935, The relation between the lowering of the piezometric surface and the rate and duration of discharge of a well using ground-water storage: Am. Geophys. Union Trans., pt. 2, p. 519-524. 3 figs.

Their, C. V., and Sayre, A. N., 1942, Geology and ground water, in [U.S.] Natl. Resources Planning Board, 1942, Pecos River Joint Investigation-Reports of the participating agencies: Washington, U.S. Govt. Printing Office, p. 27-38, 2 figs.
Theis, C. V., and others, 1942. Ground-water hydrology of areas in the Pecos Valley, New Mexico, in [U.S.] Natl. Resources Planning Board, 1942, Pecos River Joint Investigation-Reports of the participating agencies: Washington, U.S. Govt. Printing Office, p. 38-75, 11 figs.

[U.S.] National committee on radiation protection, 1959, Maximam permissible body burdens and maximum permissible concentrations of radionuclide in air and in water for occupational exposure: Natl. Bur. Standards Handbook 69: Washington, U.S. Govt. Printing Office, 95 p.

[U.S.] National Resources Planning Board. 1942, Pecos River Joint Investigation-Reports of the participating agencies: Washington, U.S. Govt. Printing Office, 407 p.

[U.S.] Public Health Service, 1962, Drinking water standards: U.S. Public Health Service Pub. 956, 61 p.

Vine, J. D., 1959, Geologic map of the Nash Draw Quadrangle, Eddy County, New Mexico: U.S. Geol. Survey TEM-830, open-file report.

1960, Recent donal structures in southeastern New Mexice: Am. Assoc. Petroleum Geologists Bull., v. 44, no. 12, p. 1903-1911, 7 figs.

U. S. GOVERNMENT PRINTING OFFICE : 1971 O - 428-472 